\title{
The Paradigm Shift in the Pakistan Stock Exchange's Financial Integration Post-FTA and CPEC
}

\author{
Abdul Wahid ${ }^{*}$ and Muhammad Zubair Mumtaz ${ }^{* *}$
}

\begin{abstract}
This paper examines whether regional connectivity causes return and volatility spillovers and the co-movement of stock exchanges to shift from international to regional markets. Using the China-Pakistan free trade agreement (FTA) of 2006 and the China-Pakistan Economic Corridor (CPEC) agreement to represent events of regional connectivity, we test this proposition based on data for two regional stock exchanges (the Pakistan Stock Exchange and Shenzhen Stock Exchange) and two global markets (the FTSE 100 and Nasdaq). We divide the convergence and co-integration of the stock markets into three phases: overall sample (2001-17), pre-FTA and post-FTA, and pre-CPEC and post-CPEC. Applying a GARCH $(1,1)$ model, co-integration, Granger causality and seasonality, we find that regional connectivity causes return and volatility spillovers and co-movements in the Pakistan Stock Exchange to shift from international markets to regional markets.
\end{abstract}

Keywords: Financial integration, China-Pakistan economic corridor, interdependency, co-integration, free trade agreement, regional connectivity, Pakistan.

JEL classification: C22, E44, F15, F21, R58.

\section{Introduction}

Globalization generally develops around the paradigm shift from localization to internationalization, which promotes the co-integration and co-movement of stock exchanges with global markets (Zhang et al., 2015). This phenomenon is based on three pillars - integration, convergence and cohesiveness (Barro, 2016) - which enable greater economic liberalization (Alikhanov, 2013), interrelated synchronization and the financial integration of full-fledged local stock exchanges with international markets (Patel, 2016).

\footnotetext{
${ }^{*}$ Lecturer, Department of Governance and Public Policy, Faculty of Management Sciences, National University of Modern Languages, Islamabad, Pakistan.

** Assistant Professor, School of Social Sciences and Humanities, National University of Science and Technology, Islamabad, Pakistan.
} 
This has garnered considerable research interest with respect to comovements and spillover effects in stock markets. Earlier studies have examined, for example, how the change in volatility and returns of one market can influence the volatility and returns of other markets, that is, how one follows the movements of the other.

The literature looks at aspects of financial integration such as the interdependency of stock exchanges (Rajhans \& Jain, 2015), the trickledown effects of integration (Morana \& Beltratti, 2008), the co-movement of prices, returns and volatilities (Sehgal et al., 2015), and correlations between developed and developing country markets (Wang \& Liu, 2016). Studies on financial integration provide investors with useful insights into international market trends and their trickledown influence over regional markets (Carsamer, 2016). This creates opportunities for international investors to develop stock portfolios for emerging economies (Bhar \& Nikolova, 2007; Sehgal et al., 2015).

After the financial crisis of 2007/08, regional connectivity, partnerships and integration have drawn greater interest. Critics of financial integration argue that it leads to the creation of market bubbles (Hatipoglu \& Uyar, 2012) and that the high interdependency of markets increases the risk of financial crisis (Morana \& Beltratti, 2008), such that highly volatile, risky markets adversely affect stable, emerging ones (Li \& Majerowska, 2008). Other studies have focused on stock exchange behavior in integrated systems (Gunasinghe, 2005) and the co-movement of multiple stock exchanges in the long and short runs (Li \& Majerowska, 2008; Masih \& Masih, 2001; Patel \& Patel, 2012) post-globalization and financial liberalism. Joshi (2011), for instance, focuses on how stock exchanges are integrated, while Mulyadi and Anwar (2012) assess to what extent they affect each other in terms of mean or volatility spillovers and over what period.

This debate is rooted in different aspects of globalization, including international partnerships, financial integration and homogeneity of operations (Sial et al., 2015). While globalization is responsible for comovement and financial integration, countries' economic relationships and their control over other stock exchanges (foreign shareholding) can also be considered major contributors to movements in financial markets (Taneja, 2012). The linkages that develop through these regional interests, strategic partnerships and stock market movements thus represent an important, if under-researched, part of the literature, to which this study contributes. 
We focus on the Pakistan Stock Exchange (PSX), which was initially more dependent on international stock markets. In 2006, Pakistan and China signed a mutual free trade agreement (FTA) to promote bilateral trade. Economic cooperation between the two countries grew over time and the China-Pakistan Economic Corridor (CPEC) agreement was established in 2015, with an estimated cost of US\$57 billion. Post-CPEC, a Chinese consortium acquired 40 percent of its shares after the PSX was demutualized (Hussain, 2016) and the latter appeared to converge from the global market to the regional market. ${ }^{1}$

Accordingly, we draw on convergence theory, which states that economic and strategic partnerships create a similar culture and business trends. In this case, the entry of Chinese investors through portfolio and foreign direct investment as well as companies' cross-listing has contributed to financial integration, economic convergence, capital market growth and economic development in the region (Hussain, 2016). These economic transactions have enabled Chinese investors to participate in the PSX's decision-making process, in turn, causing it to converge from Western markets to regional markets.

We add to the literature on the co-movement of stock exchanges and return and volatility spillovers by showing how economic and strategic partnerships can trigger movements in a country's capital market toward its partner. Specifically, we ask (i) how the returns and volatility of one country's stock market can influence its economic partner's returns and volatility, and (ii) how such partnerships can lead to co-movements in their stock exchanges.

\section{Empirical Evidence of Co-movements and Spillovers}

In a recent study, Jebran and Iqbal (2016) examine volatility spillovers between stock markets and foreign exchange markets in selected Asian economies, including Pakistan, India, Sri Lanka, China, Hong Kong and Japan. They present evidence of a bidirectional, asymmetric volatility spillover effect between the stock markets and foreign exchange markets of Pakistan, China, Hong Kong and Sri Lanka. The authors also explore the unidirectional transmission of volatility from the Indian stock market to the

\footnotetext{
${ }^{1}$ The PSX sold 40 percent of its shares to a Chinese consortium comprising the China Financial Futures Exchange Company Limited, the Shanghai Stock Exchange and Shenzhen Stock Exchange. Valued at PRs8.96 billion (roughly US\$85 million), this transaction is expected to attract foreign investment, skills, technological assistance and new product development.
} 
foreign exchange market. In Japan's case, however, there is little evidence of volatility transmission between the two markets.

Peng et al. (2017) investigate the return spillover between Taiwan's TAIEX and the Nikkei, and point to persistent (long-term) co-integration between the two indices. Examining the cross-market effect, they demonstrate how past returns on the Nikkei influence present returns on the TAIEX, although not the other way around. The study reveals the presence of an inner market leverage effect, a negative cross-market volatility spillover effect and a common price-leading effect. Looking at the two indices' relative asymmetry, the authors find that both stock markets are more sensitive to falling than rising patterns in each other.

Liow (2015) examines the contingent volatility spillover effect among five asset classes (public real estate, stocks, bonds, money and currency) locally and internationally in the G7 countries for the period 1997-2013. The author finds that persistent volatility is predominant in all domestic asset markets. The results also indicate an association between the spillover cycle co-movements of domestic business cycle fluctuations and the asset market return volatility cycle. This provides fresh insight into cross-asset and crossmarket volatility for national bank strategy makers involved in risk management and portfolio diversification for international investors.

Tanizaki and Hamori (2009) use price level and volatility to analyze spillover effects among Japan, the UK and US. They gauge the impact of return and volatility spillovers among the stock market, credit default swap (CDS) market and foreign exchange market in Korea, the US and Japan. The authors present evidence of a critical return and volatility spillover effect between the Korean CDS and stock markets. Taly (2015) points to a return spillover effect in foreign exchange markets and from the US stock market to the Korean stock market, as well as a volatility spillover effect from the Japanese stock market to the Korean stock market.

Choudhry (2004) evaluates mean and volatility spillovers between the stock exchanges of political rivals (Israel and Jordan, India and Pakistan, Greece and Turkey) and allies (the US). The results indicate bidirectional mean and volatility spillovers between two rivals and their ally (the US), but only in the short run. Dedi and Yavas (2016) examine the linkages between equity market return and volatility spillovers and the corresponding country's market (Germany, the UK, China, Russia and Turkey). The results indicate significant co-movement of returns among the sample, with Russia and Turkey exhibiting the highest volatility, while the UK and China have 
the lowest volatility spillover. All the stock exchanges except the UK and Turkey indicate volatility spillovers from other markets. The authors also find that market volatility has a positive effect on future returns only in the case of the UK.

Ely (2015) examines mean and volatility spillovers among stock markets and foreign exchange markets in Brazil. The author shows that the stock market drives the foreign exchange market in terms of price formation, with nonlinear Granger causalities from the exchange market to the stock market. Some portion of these nonlinear causalities is explained by volatility spillovers. Exchange rate volatility affects not only stock market volatility, but also stock returns. Asian markets are more sensitive to financial crises, which have a significant effect on their stock returns.

Singhania and Anchalia (2013) explore the impact of global crises on the volatility of stock returns. They find that the sub-prime crisis had a positive impact on volatility and returns in Japan, China and India, but not Hong Kong. In addition, the Euro-zone debt crisis had a negative impact on the volatility of highly volatile stock returns, such as in India and China, but this did not hold for Japan and Hong Kong. Finally, Valadkhani and Chen (2014) examine the dynamic and switching effects of volatility spillovers from the US stock market to the Australian, Canadian and UK stock markets. The study finds that US stock market volatility influences that of the other stock markets and has a significant impact on their output volatilities.

The literature review shows that the US and UK markets significantly influence regional, local and emerging markets due to financial convergence. There is also an interrelationship between return and volatility spillovers in these markets and in the PSX. We argue that CPEC and China's acquisition of 40 percent of PSX shareholdings has led to a paradigm shift, whereby changes in return and market volatility in China could now affect return and market volatility in Pakistan.

\section{Econometric Methodology}

We use the two-stage GARCH-in-mean approach (GARCH-M) to measure the spillover effects of international and regional markets on the PSX. Earlier studies have used different techniques to explain volatility spillovers between financial markets, including the GARCH, VAR-GARCH, M-GARCH, E-GARCH and GARCH-BEKK models. ${ }^{2}$ We employ the

\footnotetext{
2 See Alikhanov (2013), Carsamer (2016), Choudhry (2004), Peng et al. (2017), Dedi and Yavas
} (2016) and Joshi (2011). 
GARCH-M model specified by Pan (1997) because it provides information on volatility spillovers without having to select explanatory variables at the outset. The moving window utility allows us to proceed without specifying any break-point, which other methodologies generally require. The strength and direction of the relationship also makes this technique a far better one.

The study examines the spillover effect of international and regional markets on the PSX, using both event periods. For regional connectivity, we consider the Shenzhen Stock Exchange (SZSE), a leading Chinese index. ${ }^{3}$ Both these indices have been used elsewhere to examine the effect of investment. Drawing on daily stock market index data for the period 200117 , we divide the convergence and co-integration of stock markets into three phases: (i) 2001-17 (overall sample), (ii) pre-FTA and post-FTA, and (iii) preCPEC and post-CPEC. We use daily rather than monthly data because the latter provides no evidence of short-run integration, while using daily data yields strong evidence of mean and volatility spillovers. ${ }^{4}$

To determine the mean and volatility spillover effects of international markets on the PSX and whether it follows international or regional stock exchanges, we measure the returns of the sample stock exchanges as follows: ${ }^{5}$

$$
r_{t}=\log \left(\frac{P_{1}}{P_{0}}\right)
$$

where $r_{t}$ is the average market return of each stock exchange for day $t$, and $P_{1}$ and $P_{0}$ represent the overall weighted index. To gauge the behavior and volatility of these international indices and PSX returns, the series is modeled using the following ARMA $(1,1)-\mathrm{GARCH}(1,1)-\mathrm{M}$ model:

$$
\begin{aligned}
& r_{i, t}=\beta_{0}+\beta_{1} r_{i, t-1}+\beta_{2} V_{i, t}+\beta_{3} \mu_{i, t-1}+\mu_{i, t} \\
& \text { where } \mu_{i, t} \sim N\left(0, V_{i, t}\right) \\
& V_{i, t}=\eta_{0}+\eta_{1} V_{i, t-1}+\eta_{2} \mu_{i, t-1}^{2}
\end{aligned}
$$

where $r_{i, t}$ is the daily return of stock index $k$ (FTSE, Nasdaq and SZSE) at time $t$, and $\mu_{i, t}$ is the residual, relying on the assumption that it is normally distributed with mean 0 and time-conditional variance $V_{i, t}$. We include an

\footnotetext{
${ }^{3}$ We recognize that not using the Shanghai Stock Exchange is a limitation of this study.

${ }^{4}$ The decision to use daily data is also a limitation of this study.

${ }^{5}$ The daily market return for each index is calculated as $r_{t}=\log \left(\frac{\text { index }_{t}}{\text { index }}\right)$.
} 
ARMA $(1,1)$ and/or MA (1) structure in the model to adjust for possible serial correlation in the data. To measure the spillover effects of mean returns and volatility across market shares, we calculate the standardized residual and its square, and include these in the market returns and volatility equation as given below:

$$
\begin{aligned}
r_{j, t}= & \alpha_{0}+\alpha_{1} r_{j, t-1}+\alpha_{2} V_{j, t}+\alpha_{3} \varepsilon_{j, t-1}+\varphi_{j} \varepsilon_{i}+\varepsilon_{i, t} \\
& \text { where } \varepsilon_{j, t} \sim N\left(0, V_{j, t}\right) \\
V_{j, t}= & \delta_{0}+\delta_{1} V_{j, t-1}+\delta_{2} \varepsilon_{j, t-1}^{2}+\lambda_{j} \varepsilon_{i, t}^{2}
\end{aligned}
$$

Here, $\varepsilon_{i, t}$ is the standardized residual series for different international indices and extracts the mean return spillover effect from these indices. To measure the spillover effects of volatility, the exogenous variable $\varepsilon_{i, t}^{2}$, the square of the standardized residual series $\left(u t^{2}\right)$, is included in the conditional volatility equation.

Next, we examine the co-movement of stock exchanges using the Granger causality test and Johansen co-integration test. The first step is to determine whether the time-series variables are nonstationary with unit root $\mathrm{I}(1)$ and I(0), for which purpose we use the augmented Dickey-Fuller (ADF) and Phillips-Perron (PP) tests. In Granger's (1986) model, if the values of X predict the value of $\mathrm{Y}$ in a confined way, it implies that $x$ causes $y$. The variable fails to Granger-cause $y_{t}$ if

$$
\operatorname{Pr}\left(y_{t+m} \mid \delta\right)=\operatorname{Pr}\left(y_{t+m} \mid \gamma_{t}\right)
$$

where $\operatorname{Pr}\left(y_{t+m} \mid \delta\right)$ identifies the conditional probability of $y_{t}$ while $x_{t}$ is the set of all information available at time $t \cdot \operatorname{Pr}\left(y_{t+m} \mid \gamma_{t}\right)$ indicates the conditional probability of $y_{t}$ obtained by excluding all information on $x_{t}$ from $y_{t}$. This set of information is represented by $W_{t}$. The causal relationship between the stationery series is estimated as:

$$
\begin{aligned}
& x_{t}=\beta_{0}+\sum_{j=1}^{k} \delta_{j} x_{t-j}+\sum_{j=1}^{k} \eta_{j} y_{t-j}+\mu_{x t} \\
& y_{t}=\beta_{0}+\sum_{j=1}^{k} \delta_{j} x_{t-j}+\sum_{j=1}^{k} \eta_{j} y_{t-j}+\mu_{y t}
\end{aligned}
$$

where $k$ is a positive integer, $\delta_{j}$ and $\eta_{j}(j=0,1, \ldots, k)$ are parameters, $\beta$ is a constant and $\mu_{t}$ is a disturbance term with zero means and finite variances. The null hypothesis states that $y$ does not cause $x$. The lag is gauged using the Akaike information criterion (AIC) to measure co-movement by defining a vector of $n$ potentially endogenous variables, $Z_{t}$. 


$$
Z=A i Z_{a-1} \ldots+A_{k} Z_{t-k}+\delta D_{t}+\mu_{e t}
$$

where $A_{i}$ is the coefficients' matrix, $n$ is a constant, $D_{t}$ denotes seasonal dummies orthogonal to the constant term and $\mu$ is assumed to be an independent and identically distributed Gaussian process.

To determine how the sample stock exchanges reacted to the financial crisis of 2007/08, we use the seasonality method, which gauges the behavior and movement of time-series data that has experienced significant changes in a specific period in an extraordinary situation. In this case, seasonality refers to fluctuations in stock indices that occurred due to the financial crisis of 2007/08 (Fedderke \& Marinkov, 2016). We use OLS to determine index behavior during the crisis. The dependent variable is the stock index. The independent variables are divided into three categories: pre-crisis (BC1BC5), crisis (2007/08) (CRS1-CRS2) and post-crisis (2009-13) (ACRS1ACRS5). These are quantified as 1 for the same year and 0 otherwise (Hussain et al., 2015). The econometric equation used is:

$$
Y_{t}=\varphi_{0}+\varphi_{1} D_{t B c 1-B C 6}+\varphi_{2} D_{t C R S 1-C R S 2}+\varphi_{3} D_{t A C R S 1-A C R S 9}+\mu_{t}
$$

The model includes only qualitative regressor-different categories of years, assigning a value of 1 if the observation belongs to that year and 0 otherwise. $Y_{t}$ is the average annual index, and $D_{t}=1$ if the observation relates to the same year and 0 otherwise.

We apply the F-test to establish the pre-sample and post-sample variance in each data stream. The $t$-test is used to compare statistical models as per the dataset provided.

$$
F \text { value }=\frac{\sigma_{1}^{2}}{\sigma_{2}^{2}}
$$

To apply an F distribution under the null hypothesis, we determine the mean of two given observations (pre-event and post-event) and then calculate their variance:

$$
\sigma^{2}=\frac{\sum(x-\bar{x})^{2}}{n-1}
$$

where $\sigma^{2}$ is the variance, $x$ denotes the values given in a set of data, $\bar{x}$ is the mean data and $n$ is the total number of observations. 


\section{Findings and Discussion}

Table 1 provides descriptive statistics for the entire sample. The PSX trends upward, growing continuously. The SZSE, a developing stock market, shows extraordinary performance.

Table 1: Descriptive statistics for stock indices, 2001-17

\begin{tabular}{lcccc}
\hline & SZSE & PSX & FTSE 100 & Nasdaq \\
\hline Mean & 827 & 15,082 & 2,757 & 5,588 \\
Maximum & 3,141 & 50,192 & 5,914 & 7,103 \\
Minimum & 237 & 1,075 & 1,114 & 3,287 \\
SD & 431 & 12,151 & 1,074 & 872 \\
Skewness & 1.06 & 1.04 & 0.87 & -0.45 \\
Kurtosis & 5.62 & 3.06 & 2.65 & 2.18 \\
Jarque-Bera & $1,958.40$ & 740.174 & 538.931 & 252.618 \\
Prob. & 0.000 & 0.000 & 0.000 & 0.000 \\
\hline
\end{tabular}

Source: Authors' calculations

\subsection{Overall Sample, 2001-17}

We use the GARCH variance equation to test the mean return spillover and volatility of each index. Table 2 gives the results for the overall sample, indicating that the PSX captures the mean and volatility effects of the FTSE 100 (mean $(\varphi)=-0.0087$, volatility $(\lambda)=0.0005$ at $p<0.05)$ and Nasdaq (mean $(\varphi)=0.0074$, volatility $(\lambda)=0.0003$ ) at $p<0.05$ ). We can infer, therefore, that the PSX does not capture the mean and volatility effects of the SZSE $($ mean $(\varphi)=-0.0080$, volatility $(\lambda)=0.00003$ at $p>0.05)$. 
Table 2: Mean and volatility spillovers from global and regional markets to PSX, 2001-17

\begin{tabular}{|c|c|c|c|c|c|c|}
\hline & \multicolumn{2}{|c|}{ FTSE 100 vs PSX } & \multicolumn{2}{|c|}{ Nasdaq vs PSX } & \multicolumn{2}{|c|}{ SZSE vs PSX } \\
\hline & FTSE 100 & PSX & Nasdaq & PSX & SZSE & PSX \\
\hline$\beta_{0}$ & $\begin{array}{l}-0.1804 \\
(2.1605)\end{array}$ & $\begin{array}{c}0.0011 \\
(0.0002)\end{array}$ & $\begin{array}{l}-0.0009 \\
(0.0007)\end{array}$ & $\begin{array}{c}0.0011 \\
(0.0002)\end{array}$ & $\begin{array}{c}0.0002 \\
(0.0001)\end{array}$ & $\begin{array}{c}0.0011 \\
(0.0002)\end{array}$ \\
\hline$\beta_{1}$ & $\begin{array}{l}-0.0009 \\
(0.0001)\end{array}$ & $\begin{array}{c}0.1746 \\
(0.1702)\end{array}$ & $\begin{array}{c}2.4472 \\
(1.0619)\end{array}$ & $\begin{array}{c}0.1746 \\
(0.1702)\end{array}$ & $\begin{array}{l}-0.0479 \\
(0.2770)\end{array}$ & $\begin{array}{c}0.1746 \\
(0.1702)\end{array}$ \\
\hline$\beta_{2}$ & $\begin{array}{c}2.4215 \\
(1.0792)\end{array}$ & $\begin{array}{l}-0.0622 \\
(0.1728)\end{array}$ & $\begin{array}{l}-2.4639 \\
(1.0634)\end{array}$ & $\begin{array}{l}-0.0622 \\
(0.1728)\end{array}$ & $\begin{array}{c}0.1079 \\
(0.2758)\end{array}$ & $\begin{array}{c}-0.0622 \\
(0.1728)\end{array}$ \\
\hline$\beta_{3}$ & $\begin{array}{l}-2.4382 \\
(1.0812)\end{array}$ & & $\begin{array}{l}-0.0009 \\
(0.0008)\end{array}$ & & $\begin{array}{l}-0.0044 \\
(1.006)\end{array}$ & \\
\hline$\varphi$ & & $\begin{array}{c}-0.0087^{* *} \\
(0.0104)\end{array}$ & & $\begin{array}{l}0.0074^{*} \\
(0.0113)\end{array}$ & & $\begin{array}{c}-0.0080 \\
(0.0095)\end{array}$ \\
\hline$\delta_{0}$ & $\begin{array}{c}0.0001 \\
(0.0024)\end{array}$ & $\begin{array}{c}0.0040 \\
(0.0055)\end{array}$ & $\begin{array}{c}0.0001 \\
(0.0002)\end{array}$ & $\begin{array}{c}0.0004 \\
(0.0005)\end{array}$ & $\begin{array}{l}-0.0001 \\
(0.0001)\end{array}$ & $\begin{array}{c}0.0004 \\
(0.0001)\end{array}$ \\
\hline$\delta_{1}$ & $\begin{array}{l}0.0708^{* *} \\
(0.0100)\end{array}$ & $\begin{array}{l}0.1851^{* *} \\
(0.0099)\end{array}$ & $\begin{array}{l}0.0709^{* *} \\
(0.0100)\end{array}$ & $\begin{array}{l}0.1851^{* *} \\
(0.0099)\end{array}$ & $\begin{array}{l}0.1334^{* *} \\
(0.0023)\end{array}$ & $\begin{array}{l}0.1851^{* *} \\
(0.0099)\end{array}$ \\
\hline$\delta_{2}$ & $\begin{array}{l}0.8487^{* *} \\
(0.0200)\end{array}$ & $\begin{array}{l}0.7689 * * \\
(0.0087)\end{array}$ & $\begin{array}{l}0.8486^{* *} \\
(0.0200)\end{array}$ & $\begin{array}{l}0.7689^{* *} \\
(0.0087)\end{array}$ & $\begin{array}{l}0.8882^{* *} \\
(0.0014)\end{array}$ & $\begin{array}{l}0.7689^{* *} \\
(0.0087)\end{array}$ \\
\hline$\lambda$ & & $\begin{array}{l}0.0005^{* *} \\
(0.0003)\end{array}$ & & $\begin{array}{l}0.0003^{* *} \\
(0.0002)\end{array}$ & & $\begin{array}{l}0.0001^{* *} \\
(0.0001)\end{array}$ \\
\hline & & & dual diag & tics & & \\
\hline $\mathrm{Q}(24)$ & 0.531 & 0.129 & 0.331 & 0.129 & 0.014 & 0.129 \\
\hline Q (24) sq. & 0.976 & 0.189 & 1.000 & 0.189 & 0.791 & 0.189 \\
\hline
\end{tabular}

Note: This table gives the daily market returns of the PSX, Nasdaq, FTSE 100 and SZSE from January 2001 to January 2017, using an ARMA (1, 1)-GARCH $(1,1)-\mathrm{M}$ model. Standard errors are reported in parentheses. The residual diagnostics are presented as $p$-values. $Q$ (24) is the portmanteau statistic, which explains the null hypothesis of no residual serial correlations, gauged through a lag of 24 . Using the same method, Q (24) sq. indicates the null hypothesis of no residual ARCH effect. ${ }^{*}$ and ${ }^{* *}$ denote significance at 95 percent $(p<$ $0.05)$ and 99 percent $(p<0.01)$, respectively.

Source: Authors' calculations.

These findings are in line with convergence theory, suggesting that small local markets such as the PSX converge on their financial origin, that is, industrialized and digitalized markets such as the Nasdaq and FTSE 100. Since the integration of these markets cannot occur in isolation, any systematic and unsystematic risks in the global market will not only affect returns, but also create volatility in regional and local markets (Rajhans \& Jain, 2015). This finding implies that Pakistan's economy was integrated financially and socially with the US and UK markets during 2001-17. Any substantial changes in these markets had a significant impact on the PSX (Figure 1). 


\section{Figure 1: Volatility of market returns, 2001-17}

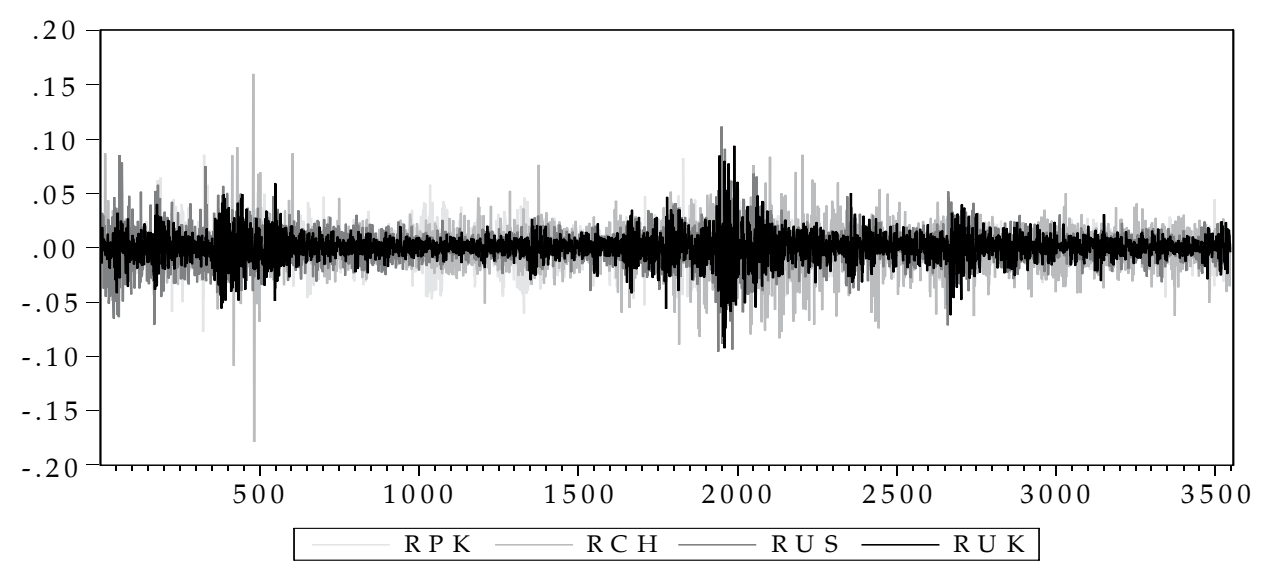

We apply the ADF and PP tests to measure co-movement among the stock exchange indices. The results for all the indices over the period 200117 are nonstationary at level and stationary at first difference (Table A1 in the Appendix). To measure the lag length, we use the log likelihood method, AIC an Schwarz information criterion (SIC). The results indicate an appropriate lag order of 3 and the vector decomposition is thus estimated using this lag order (Table A2 in the Appendix).

Table 3 presents the short-run co-movements of the PSX with the SZSE, Nasdaq and FTSE $100(0.0016, p<0.05 ; 0.0005, p<0.05$; and -0.0081 , $p<0.05$, respectively) as well as its long-run co-movements with the SZSE, Nasdaq and FTSE $100(0.0079, p<0.001 ; 0.0011, p<0.001$; and $0.0023, p<$ 0.001 , respectively). The results imply that the co-movements in this series are negative in the short term and medium term, but positive and persistent in the long term. The results for the mean and volatility spillovers and co-movement series support convergence theory, demonstrating that small domestic markets such as the PSX converge on their financial origin, that is, industrialized, digitalized markets such as the Nasdaq and FTSE 100 (Figure 2). 
Table 3: Co-movement of indices, 2001-17

\begin{tabular}{lccccccccc}
\hline & PSX & Nasdaq & FTSE 100 & SZSE & & PSX & Nasdaq & FTSE 100 & SZSE \\
\hline PSX (-1) & 1.1300 & -0.0016 & 0.0005 & -0.0081 & FTSE100 (-1) & 0.0665 & 0.0060 & 0.9439 & 0.0133 \\
& -0.0167 & -0.0037 & -0.0052 & -0.0020 & & -0.0501 & -0.0110 & -0.0156 & -0.0059 \\
& {$[67.871]$} & {$[-0.436]$} & {$[0.098]$} & {$[-4.100]$} & & {$[1.327]$} & {$[0.544]$} & {$[60.37]$} & {$[2.253]$} \\
PSX (-2) & -0.1621 & -0.0054 & -0.0017 & 0.0057 & FTSE100 (-1) & -0.0856 & 0.0060 & 0.0109 & -0.0110 \\
& -0.0253 & -0.0056 & -0.0079 & -0.0030 & & -0.0690 & -0.0152 & -0.0215 & -0.0082 \\
& {$[-6.415]$} & {$[-0.971]$} & {$[-0.212]$} & {$[1.911]$} & & {$[-1.240]$} & {$[0.394]$} & {$[0.506]$} & {$[-1.347]$} \\
\multirow{5}{*}{ PSX (-3) } & 0.0330 & 0.0079 & 0.0011 & 0.0023 & FTSE100 (-1) & 0.0147 & -0.0125 & 0.0357 & -0.0024 \\
& -0.0167 & -0.0037 & -0.0052 & -0.0020 & & -0.0500 & -0.0110 & -0.0156 & -0.0059 \\
& {$[1.968]$} & {$[2.161]$} & {$[0.217]$} & {$[1.182]$} & & {$[0.294]$} & {$[-1.141]$} & {$[2.287]$} & {$[-0.399]$} \\
Nasdaq (-1) & -0.0427 & 0.9823 & 0.0092 & -0.0120 & SZSE $(-1)$ & -0.1928 & 0.0355 & -0.0501 & 1.1598 \\
& -0.0720 & -0.0158 & -0.0225 & -0.0085 & & -0.1419 & -0.0312 & -0.0443 & -0.0168 \\
& {$[-0.593]$} & {$[62.116]$} & {$[0.409]$} & {$[-1.414]$} & & {$[-1.358]$} & {$[1.138]$} & {$[-1.130]$} & {$[69.13]$} \\
Nasdaq (-2) & -0.0809 & -0.0201 & 0.0093 & 0.0028 & SZSE $(-2)$ & 0.6253 & 0.0538 & 0.0010 & -0.0994 \\
& -0.1011 & -0.0222 & -0.0315 & -0.0120 & & -0.2170 & -0.0477 & -0.0677 & -0.0257 \\
& {$[-0.800]$} & {$[-0.903]$} & {$[0.293]$} & {$[0.231]$} & & {$[2.882]$} & {$[1.129]$} & {$[0.014]$} & {$[-3.874]$} \\
Nasdaq (-3) & 0.1260 & 0.0293 & -0.0094 & 0.0106 & SZSE $(-3)$ & -0.4485 & -0.0936 & 0.0407 & -0.0635 \\
& -0.0720 & -0.0158 & -0.0225 & -0.0085 & & -0.1419 & -0.0312 & -0.0443 & -0.0168 \\
& {$[1.750]$} & {$[1.852]$} & {$[-0.416]$} & {$[1.239]$} & & {$[-3.161]$} & {$[-3.005]$} & {$[0.919]$} & {$[-3.787]$} \\
& 27.5393 & 16.8009 & 35.5885 & -0.2417 & & & & & \\
& -27.9858 & -6.1466 & -8.7331 & -3.3089 & & & & & \\
& {$[0.984]$} & {$[2.733]$} & {$[4.075]$} & {$[-0.073]$} & & & & & \\
\hline
\end{tabular}

Source: Authors' calculations.

Figure 2: Co-movement of market returns, 2001-17

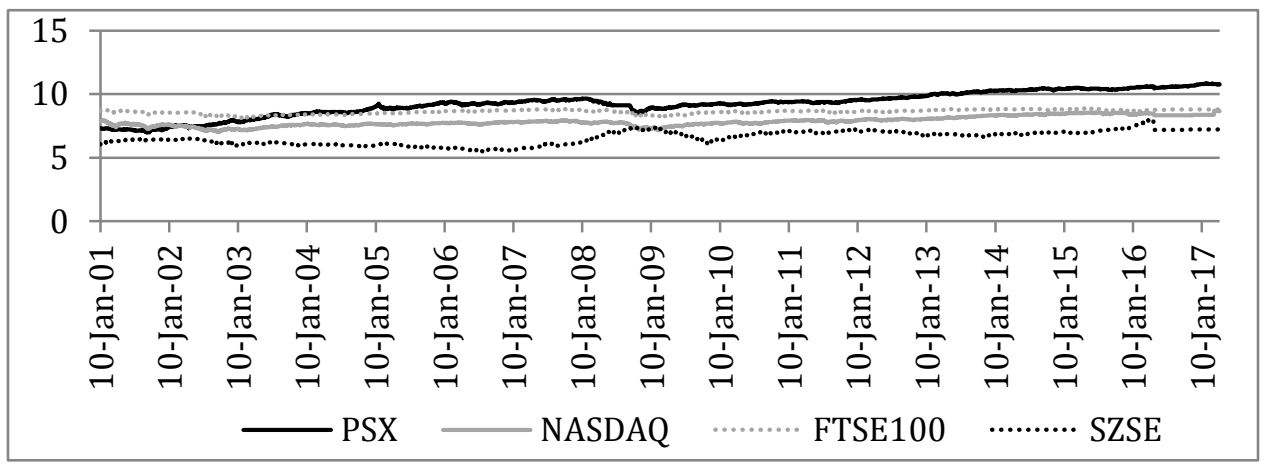

\subsection{Pre-FTA and Post-FTA}

For the FTA signed between Pakistan and China in 2006, we divide the sample into pre-event and post-event subsamples, both spanning five years. The overall results show that the PSX captures the mean and volatility effects of all the other indices before and after the event. Table 4 gives the results of the GARCH variance analysis for all series before and after the event: PSX $(0.578, p<0.001 ; 0.265, p<0.001)$; SZSE $(0.087, p<0.001 ; 0.0436, p$ $<0.001)$; Nasdaq (0.077, $p<0.001 ; 0.044, p<0.001)$; and FTSE $100(0.129, p<$ 
$0.001 ; 0.113, p<0.001)$. The results imply that these markets are volatile and responsive to economic shocks. They also point to the level of persistency in information and its effects on volatility.

\section{Table 4: Mean and volatility spillovers from global and regional indices to PSX, 2001-11}

\begin{tabular}{|c|c|c|c|c|c|c|c|c|c|c|c|c|}
\hline \multirow[b]{3}{*}{$\beta_{0}$} & \multicolumn{6}{|c|}{ Five years' data pre-FTA (Nov 2001-Nov 2006) } & \multicolumn{6}{|c|}{ Five years' data post-FTA (Nov 2006-Nov 2011) } \\
\hline & \multicolumn{2}{|c|}{$\begin{array}{c}\text { FTSE } 100 \text { vs } \\
\text { PSX }\end{array}$} & \multicolumn{2}{|c|}{ Nasdaq vs PSX } & \multicolumn{2}{|c|}{ SZSE vs PSX } & \multicolumn{2}{|c|}{$\begin{array}{l}\text { FTSE } 100 \text { vs } \\
\text { PSX }\end{array}$} & \multicolumn{2}{|c|}{ Nasdaq vs PSX } & \multicolumn{2}{|c|}{ SZSE vs PSX } \\
\hline & $\begin{array}{l}-0.067 \\
(0.001)\end{array}$ & $\begin{array}{l}-0.002 \\
(0.002)\end{array}$ & $\begin{array}{l}-0.020 \\
(0.056)\end{array}$ & $\begin{array}{c}0.007 \\
(0.010)\end{array}$ & $\begin{array}{l}-0.003 \\
(0.001)\end{array}$ & $\begin{array}{c}0.001 \\
(0.001)\end{array}$ & $\begin{array}{l}-0.025 \\
(0.061)\end{array}$ & $\begin{array}{c}0.001 \\
(0.005)\end{array}$ & $\begin{array}{l}-0.001 \\
(0.001)\end{array}$ & $\begin{array}{c}0.001 \\
(0.005)\end{array}$ & $\begin{array}{l}-0.015 \\
(0.066)\end{array}$ & $\begin{array}{c}0.001 \\
(0.005)\end{array}$ \\
\hline$\beta_{1}$ & $\begin{array}{l}-0.321 \\
(0.190)\end{array}$ & $\begin{array}{c}0.739 \\
(0.169)\end{array}$ & $\begin{array}{c}0.479 \\
(0.473)\end{array}$ & $\begin{array}{c}0.682 \\
(0.154)\end{array}$ & $\begin{array}{c}0.821 \\
(0.681)\end{array}$ & $\begin{array}{c}0.464 \\
(0.293)\end{array}$ & $\begin{array}{c}0.622 \\
(0.772)\end{array}$ & $\begin{array}{c}1.603 \\
(1.901)\end{array}$ & $\begin{array}{l}-1.381 \\
(1.610)\end{array}$ & $\begin{array}{c}1.469 \\
(1.906)\end{array}$ & $\begin{array}{c}2.415 \\
(2.151)\end{array}$ & $\begin{array}{c}1.461 \\
(1.929)\end{array}$ \\
\hline$\beta_{2}$ & $\begin{array}{c}0.123 \\
(0.344)\end{array}$ & $\begin{array}{l}-0.522 \\
(0.383)\end{array}$ & $\begin{array}{l}-1.102 \\
(0.930)\end{array}$ & $\begin{array}{l}-0.377 \\
(0.356)\end{array}$ & $\begin{array}{l}-0.517 \\
(1.318)\end{array}$ & $\begin{array}{c}0.066 \\
(0.754)\end{array}$ & $\begin{array}{l}-3.094 \\
(1.363)\end{array}$ & $\begin{array}{c}0.029 \\
(2.320)\end{array}$ & $\begin{array}{l}1.328 \\
(2.077)\end{array}$ & $\begin{array}{c}0.525 \\
(2.265)\end{array}$ & $\begin{array}{l}-3.371 \\
(2.428)\end{array}$ & $\begin{array}{c}0.395 \\
(2.296)\end{array}$ \\
\hline$\beta_{3}$ & $\begin{array}{l}-0.054 \\
(0.021)\end{array}$ & $\begin{array}{l}-0.009 \\
(0.398)\end{array}$ & $\begin{array}{c}0.518 \\
(0.782)\end{array}$ & $\begin{array}{l}-0.098 \\
(0.377)\end{array}$ & $\begin{array}{l}-0.229 \\
(0.978)\end{array}$ & $\begin{array}{l}-0.253 \\
(0.722)\end{array}$ & $\begin{array}{c}2.407 \\
(1.151)\end{array}$ & $\begin{array}{l}-1.601 \\
(1.145)\end{array}$ & $\begin{array}{c}0.091 \\
(1.050)\end{array}$ & $\begin{array}{l}-1.966 \\
(1.125)\end{array}$ & $\begin{array}{c}0.939 \\
(1.025)\end{array}$ & $\begin{array}{l}-1.833 \\
(1.130)\end{array}$ \\
\hline$\varphi$ & & $\begin{array}{c}0.002 \\
(0.020)\end{array}$ & & $\begin{array}{l}-0.004 \\
(0.007)\end{array}$ & & $\begin{array}{c}0.016 \\
(0.072)\end{array}$ & & $\begin{array}{l}-0.084 \\
(0.075)\end{array}$ & & $\begin{array}{c}0.082 \\
(0.065)\end{array}$ & & $\begin{array}{l}0.045^{* *} \\
(0.052)\end{array}$ \\
\hline$\delta_{0}$ & $\begin{array}{c}0.023 \\
(0.011)\end{array}$ & $\begin{array}{c}0.002 \\
(0.002)\end{array}$ & $\begin{array}{c}0.003 \\
(0.001)\end{array}$ & $\begin{array}{c}0.003 \\
(0.002)\end{array}$ & $\begin{array}{c}0.010 \\
(0.004)\end{array}$ & $\begin{array}{c}0.002 \\
(0.008)\end{array}$ & $\begin{array}{c}0.0027 \\
(0.0013)\end{array}$ & $\begin{array}{c}0.002 \\
(0.004)\end{array}$ & $\begin{array}{c}0.004 \\
(0.001)\end{array}$ & $\begin{array}{c}0.001 \\
(0.005)\end{array}$ & $\begin{array}{c}0.004 \\
(0.003)\end{array}$ & $\begin{array}{c}0.001 \\
(0.004)\end{array}$ \\
\hline$\delta_{1}$ & $\begin{array}{c}0.134 \\
(0.039)\end{array}$ & $\begin{array}{c}0.578 \\
(0.064)\end{array}$ & $\begin{array}{c}0.077 \\
(0.020)\end{array}$ & $\begin{array}{c}0.678 \\
(0.054)\end{array}$ & $\begin{array}{c}0.087 \\
(0.015)\end{array}$ & $\begin{array}{c}0.139 \\
(0.036)\end{array}$ & $\begin{array}{c}0.1133 \\
(0.0382)\end{array}$ & $\begin{array}{c}0.265 \\
(0.060)\end{array}$ & $\begin{array}{c}0.044 \\
(0.024)\end{array}$ & $\begin{array}{c}0.272 \\
(0.062)\end{array}$ & $\begin{array}{l}0.0436 \\
(0.032)\end{array}$ & $\begin{array}{c}0.272 \\
(0.063)\end{array}$ \\
\hline$\delta_{2}$ & $\begin{array}{c}0.456 \\
(0.012)\end{array}$ & $\begin{array}{l}0.593^{*} \\
(0.028)\end{array}$ & $\begin{array}{c}0.902 \\
(0.020)\end{array}$ & $\begin{array}{l}0.602^{*} \\
(0.019)\end{array}$ & $\begin{array}{c}0.881 \\
(0.023)\end{array}$ & $\begin{array}{c}0.559 \\
(0.195)\end{array}$ & $\begin{array}{c}0.8226 \\
(0.0567)\end{array}$ & $\begin{array}{l}0.699^{*} \\
(0.048)\end{array}$ & $\begin{array}{c}0.901 \\
(0.046)\end{array}$ & $\begin{array}{l}0.693^{*} \\
(0.051)\end{array}$ & $\begin{array}{l}0.6617 \\
(0.272)\end{array}$ & $\begin{array}{c}0.691 \\
(0.052)\end{array}$ \\
\hline$\lambda$ & & $\begin{array}{l}-0.045^{* *} \\
(0.0123) \\
\end{array}$ & & $\begin{array}{c}-0.001^{* *} \\
(0.003)\end{array}$ & & $\begin{array}{l}0.002^{* *} \\
(0.001)\end{array}$ & & $\begin{array}{l}0.078^{* *} \\
(0.004)\end{array}$ & & $\begin{array}{l}0.145^{* *} \\
(0.000)\end{array}$ & & $\begin{array}{c}0.0123^{* *} \\
(0.002)\end{array}$ \\
\hline & & & & & Residu & 1 diagn & ostics & & & & & \\
\hline$Q(24)$ & 0.890 & 0.611 & 0.891 & 0.450 & 0.771 & 0.063 & 0.270 & 0.630 & 0.868 & 0.548 & 0.310 & 0.534 \\
\hline Q (24) sq. & 0.788 & 0.869 & 0.901 & 0.338 & 0.538 & 0.012 & 0.340 & 0.854 & 0.591 & 0.982 & 0.465 & 0.983 \\
\hline
\end{tabular}

Note: Standard errors are reported in parentheses. The residual diagnostics are presented as p-values. Q (24) is the portmanteau statistic, which explains the null hypothesis of no residual serial correlations, gauged through a lag of 24 . Using the same method, Q (24) sq. indicates the null hypothesis of no residual ARCH effect. ${ }^{*}$ and ${ }^{* *}$ denote significance at 95 percent $(p<0.05)$ and 99 percent $(p<0.01)$, respectively.

Source: Authors' calculations.

The sum of the GARCH coefficients for all the indices is close to 1 just before the pre-FTA and post-FTA points, indicating that shocks are persistent and that forecast conditional volatility takes longer to stabilize around the variance. The results suggest that all the indices exert some influence over the PSX in terms of mean spillover pre-FTA and post-FTA, but that this impact is highest for the SZSE post-FTA. The PSX also captures volatility effects preFTA and post-FTA: its post-FTA volatility is affected the most by the FTSE 100 and Nasdaq. Overall, the PSX appears to capture the volatility effects of these global markets during the period 2001-11 (Figures 3 and 4). 
Figure 3: Pre-FTA volatility of returns

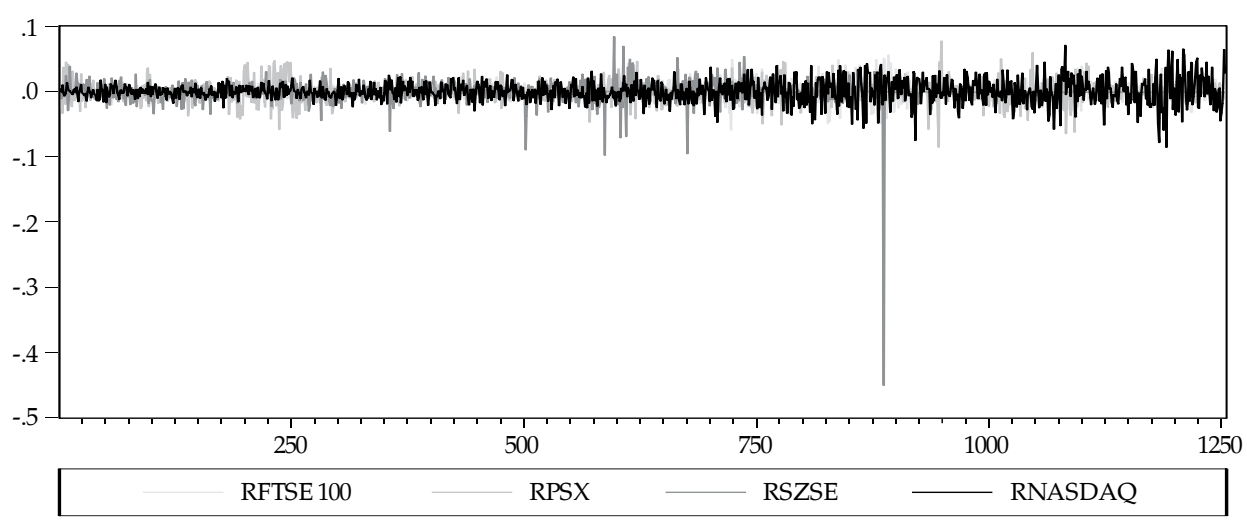

Figure 4: Post-FTA volatility of returns

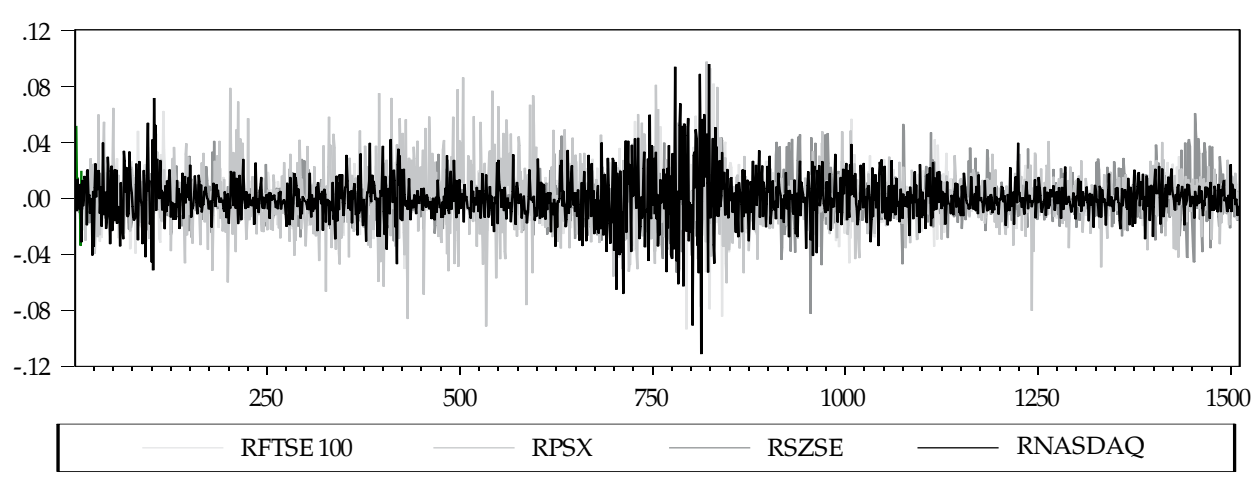

We use the ADF and PP tests to measure the co-movement among the indices. The results for all the indices over the period 2013-17 are nonstationary at level and stationary at first difference (Table A3 in the Appendix). To measure the lag length, we use the log likelihood, AIC and SIC (Table A4 in the Appendix). The results in Table 5 indicate the short-run and long-run co-movements of the PSX with all the indices under observation during 2001-11. While the co-movements in the short term and medium term are negative, they are positive and persistent in the long run (Figure 5). The results for mean and volatility spillovers and co-movements in the series support convergence theory, implying that small domestic markets such as the PSX converge on their financial origin, that is, industrialized, digitalized markets such as the Nasdaq and FTSE 100. 
Table 5: Co-movement of indices, 2001-11

\begin{tabular}{|c|c|c|c|c|c|c|c|c|c|}
\hline & PSX & SZSE & Nasdaq & FTSE 100 & & PSX & SZSE & Nasdaq & FTSE 100 \\
\hline \multirow[t]{3}{*}{ 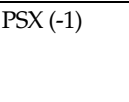 } & 1.130 & -0.008 & -0.002 & 0.001 & SZSE (-1) & -0.193 & 1.160 & 0.035 & -0.050 \\
\hline & -0.017 & -0.002 & -0.004 & -0.005 & & -0.142 & -0.017 & -0.031 & -0.044 \\
\hline & [67.874] & {$[-4.100]$} & {$[-0.436]$} & [0.098] & & {$[-1.358]$} & [69.131] & [1.138] & {$[-1.130]$} \\
\hline \multirow[t]{3}{*}{ PSX (-2) } & -0.162 & 0.006 & -0.005 & -0.002 & SZSE (-2) & 0.625 & -0.099 & 0.054 & 0.001 \\
\hline & -0.025 & -0.003 & -0.006 & -0.008 & & -0.217 & -0.026 & -0.048 & -0.068 \\
\hline & {$[-6.415]$} & [1.911] & {$[-0.971]$} & {$[-0.212]$} & & [2.882] & {$[-3.874]$} & [1.129] & {$[0.014]$} \\
\hline \multirow[t]{3}{*}{ PSX (-3) } & 0.033 & 0.002 & 0.008 & 0.001 & SZSE (-3) & -0.448 & -0.064 & -0.094 & 0.041 \\
\hline & -0.017 & -0.002 & -0.004 & -0.005 & & -0.142 & -0.017 & -0.031 & -0.044 \\
\hline & [1.968] & [1.182] & [2.161] & [0.217] & & {$[-3.161]$} & {$[-3.787]$} & {$[-3.005]$} & [0.919] \\
\hline \multirow[t]{3}{*}{ Nasdaq (-1) } & -0.043 & -0.012 & 0.982 & 0.009 & FTSE100 (-1) & 0.0665 & 0.0133 & 0.0060 & 0.9439 \\
\hline & -0.072 & -0.009 & -0.016 & -0.022 & & -0.0501 & -0.0059 & -0.0110 & -0.0156 \\
\hline & {$[-0.593]$} & {$[-1.414]$} & [62.116] & [0.409] & & [1.327] & [2.253] & {$[0.544]$} & [60.372] \\
\hline \multirow[t]{3}{*}{ Nasdaq (-2) } & -0.081 & 0.003 & -0.020 & 0.009 & FTSE100 (-2) & -0.0856 & -0.0110 & 0.0060 & 0.0109 \\
\hline & -0.101 & -0.012 & -0.022 & -0.032 & & -0.0690 & -0.0082 & -0.0152 & -0.0215 \\
\hline & {$[-0.800]$} & [0.231] & {$[-0.907]$} & [0.293] & & {$[-1.240]$} & {$[-1.347]$} & [0.394] & [0.506] \\
\hline \multirow[t]{3}{*}{ Nasdaq (-3) } & 0.126 & 0.011 & 0.029 & -0.009 & FTSE100 (-3) & 0.0147 & -0.0024 & -0.0125 & 0.0357 \\
\hline & -0.072 & -0.009 & -0.016 & -0.022 & & -0.0500 & -0.0059 & -0.0110 & -0.0156 \\
\hline & {$[1.750]$} & [1.239] & [1.852] & {$[-0.416]$} & & [0.294] & {$[-0.399]$} & {$[-1.141]$} & [2.287] \\
\hline \multirow[t]{3}{*}{ C } & 27.539 & -0.242 & 16.801 & 35.589 & & & & & \\
\hline & -27.986 & -3.309 & -6.147 & -8.733 & & & & & \\
\hline & [0.984] & {$[-0.073]$} & [2.733] & [4.075] & & & & & \\
\hline
\end{tabular}

Note: The figures below the estimates are p-values and those in brackets are standard errors. The lag length of co-integration is set at 3 . The trace statistics indicate two cointegrating equations at the 0.05 significance level.

Source: Authors' calculations.

Figure 5: Co-movement of market returns, 2001-11

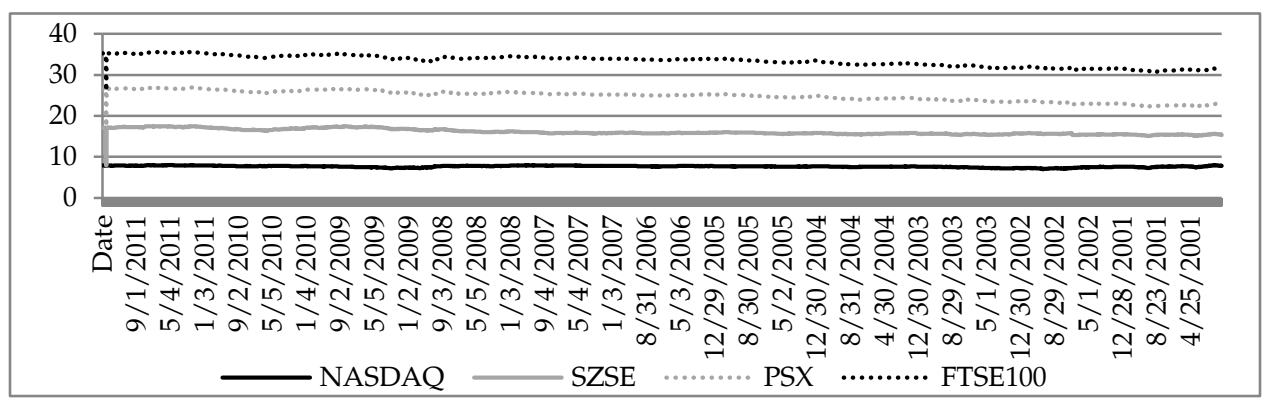

\subsection{Pre-CPEC and Post-CPEC}

The CPEC agreement between Pakistan and China was signed on $20^{\text {th }}$ April 2015 and aims to bolster trade between the two countries. Given its likely influence over the PSX, we investigate the latter's convergence on international or regional stock markets. Table 6 gives the results of the GARCH mean and variance analysis for all pre-CPEC and post-CPEC series. The sum of the GARCH coefficients of all the indices is almost 1 in both cases (pre-event and post-event), indicating that shocks are persistent and that 
forecast conditional volatility takes longer to stabilize around the variance (Figures 6 and 7). Both series suggest that the PSX does not capture the preevent or post-event mean effects of the indices, barring the SZSE. This implies that, post-CPEC, the PSX has shifted toward the regional market.

\section{Table 6: Mean and volatility spillovers from global and regional indices to PSX, 2013-17}

\begin{tabular}{|c|c|c|c|c|c|c|c|c|c|c|c|c|}
\hline \multirow[b]{3}{*}{$\overline{\beta_{0}}$} & \multicolumn{6}{|c|}{ Two years' data post-CPEC (Apr 2015-Apr 2017) } & \multicolumn{6}{|c|}{ Two years' data pre-CPEC (Apr 2013-Apr 2015) } \\
\hline & \multicolumn{2}{|c|}{$\begin{array}{c}\text { FTSE } 100 \text { vs } \\
\text { PSX }\end{array}$} & \multicolumn{2}{|c|}{ Nasdaq vs PSX } & \multicolumn{2}{|c|}{ SZSE vs PSX } & \multicolumn{2}{|c|}{$\begin{array}{l}\text { FTSE } 100 \text { vs } \\
\text { PSX }\end{array}$} & \multicolumn{2}{|c|}{ Nasdaq vs PSX } & \multicolumn{2}{|c|}{ SZSE vs PSX } \\
\hline & $\begin{array}{l}-0.004 \\
(0.001)\end{array}$ & $\begin{array}{l}-0.001 \\
(0.002)\end{array}$ & $\begin{array}{l}-0.003 \\
(0.002)\end{array}$ & $\begin{array}{l}-0.006 \\
(0.002)\end{array}$ & $\begin{array}{l}-0.002 \\
(0.001)\end{array}$ & $\begin{array}{l}-0.006 \\
(0.002)\end{array}$ & $\begin{array}{c}0.004 \\
(0.011)\end{array}$ & $\begin{array}{l}-0.001 \\
(0.002)\end{array}$ & $\begin{array}{l}-0.003 \\
(0.004)\end{array}$ & $\begin{array}{l}-0.001 \\
(0.002)\end{array}$ & $\begin{array}{c}0.004 \\
(0.002)\end{array}$ & \\
\hline$\beta_{1}$ & $\begin{array}{c}0.485 \\
(0.136)\end{array}$ & $\begin{array}{c}3.432 \\
(8.007)\end{array}$ & $\begin{array}{l}-3.460 \\
(3.217)\end{array}$ & $\begin{array}{c}3.403 \\
(8.332)\end{array}$ & $\begin{array}{l}-0.494 \\
(1.050)\end{array}$ & $\begin{array}{c}3.399 \\
(8.496)\end{array}$ & $\begin{array}{c}17.226 \\
(41.607)\end{array}$ & $\begin{array}{c}0.002 \\
(0.997)\end{array}$ & $\begin{array}{l}-2.021 \\
(4.160)\end{array}$ & $\begin{array}{l}-0.038 \\
(0.996)\end{array}$ & $\begin{array}{l}-8.166 \\
(5.043)\end{array}$ & \\
\hline$\beta_{2}$ & $\begin{array}{l}-1.918 \\
(0.253)\end{array}$ & $\begin{array}{l}-2.886 \\
(7.777)\end{array}$ & $\begin{array}{c}2.553 \\
(3.461)\end{array}$ & $\begin{array}{l}-2.858 \\
(8.077)\end{array}$ & $\begin{array}{c}1.504 \\
(2.244)\end{array}$ & $\begin{array}{l}-2.854 \\
(8.243)\end{array}$ & $\begin{array}{l}-28.257 \\
(42.411)\end{array}$ & $\begin{array}{c}0.999 \\
(4.493)\end{array}$ & $\begin{array}{c}4.163 \\
(4.491)\end{array}$ & $\begin{array}{l}1.109 \\
(4.505)\end{array}$ & $\begin{array}{l}7.907 \\
(5.027)\end{array}$ & $\begin{array}{c}1.023 \\
(4.487)\end{array}$ \\
\hline$\beta_{3}$ & & $\begin{array}{l}-0.438 \\
(0.847)\end{array}$ & $\begin{array}{c}0.890 \\
(0.938)\end{array}$ & & $\begin{array}{l}-0.965 \\
(2.015)\end{array}$ & & & & & & $\begin{array}{c}0.269 \\
(0.661)\end{array}$ & \\
\hline$\varphi$ & & $\begin{array}{c}0.045 \\
(0.198)\end{array}$ & & $\begin{array}{c}0.002 \\
(0.141)\end{array}$ & & $\begin{array}{l}-0.012^{*} \\
(0.071)\end{array}$ & & $\begin{array}{l}-0.025 \\
(0.183)\end{array}$ & & $\begin{array}{c}0.090 \\
(0.136)\end{array}$ & & $\begin{array}{r}0.0 \\
(0.0\end{array}$ \\
\hline$\delta_{0}$ & $\begin{array}{c}0.001 \\
(0.007)\end{array}$ & $\begin{array}{c}0.010 \\
(0.006)\end{array}$ & $\begin{array}{c}0.004 \\
(0.001)\end{array}$ & $\begin{array}{c}0.010 \\
(0.006)\end{array}$ & $\begin{array}{c}0.004 \\
(0.002)\end{array}$ & $\begin{array}{c}0.010 \\
(0.006)\end{array}$ & $\begin{array}{c}0.005 \\
(0.002)\end{array}$ & $\begin{array}{c}0.008 \\
(0.009)\end{array}$ & $\begin{array}{c}0.002 \\
(0.010)\end{array}$ & $\begin{array}{c}0.008 \\
(0.009)\end{array}$ & $\begin{array}{c}0.014 \\
(0.011)\end{array}$ & $\begin{array}{c}0.008 \\
(0.009)\end{array}$ \\
\hline$\delta_{1}$ & $\begin{array}{l}-0.006 \\
(0.002)\end{array}$ & $\begin{array}{c}0.150 \\
(0.169)\end{array}$ & $\begin{array}{c}0.139 \\
(0.029)\end{array}$ & $\begin{array}{c}0.150 \\
(0.175)\end{array}$ & $\begin{array}{c}0.083 \\
(0.022)\end{array}$ & $\begin{array}{c}0.150 \\
(0.175)\end{array}$ & $\begin{array}{c}0.163 \\
(0.037)\end{array}$ & $\begin{array}{c}0.150 \\
(0.144)\end{array}$ & $\begin{array}{c}0.116 \\
(0.041)\end{array}$ & $\begin{array}{c}0.150 \\
(0.145)\end{array}$ & $\begin{array}{c}0.019 \\
(0.018)\end{array}$ & $\begin{array}{c}0.150 \\
(0.146)\end{array}$ \\
\hline$\delta_{2}$ & $\begin{array}{c}1.047 \\
(0.007)\end{array}$ & $\begin{array}{c}0.600 \\
(0.268)\end{array}$ & $\begin{array}{c}0.826 \\
(0.032)\end{array}$ & $\begin{array}{c}0.600 \\
(0.267)\end{array}$ & $\begin{array}{c}0.909 \\
(0.023)\end{array}$ & $\begin{array}{c}0.600 \\
(0.271)\end{array}$ & $\begin{array}{c}0.759 \\
(0.054)\end{array}$ & $\begin{array}{c}0.600 \\
(0.392)\end{array}$ & $\begin{array}{c}0.756 \\
(0.089)\end{array}$ & $\begin{array}{c}0.600 \\
(0.393)\end{array}$ & $\begin{array}{c}0.909 \\
(0.102)\end{array}$ & $\begin{array}{c}0.600 \\
(0.394)\end{array}$ \\
\hline$\lambda$ & & $\begin{array}{c}0.009 \\
(0.006)\end{array}$ & & $\begin{array}{c}0.008 \\
(0.008)\end{array}$ & & $\begin{array}{l}0.023^{* *} \\
(0.011)\end{array}$ & & $\begin{array}{l}0.002^{*} \\
(0.001)\end{array}$ & & $\begin{array}{l}0.003^{*} \\
(0.001)\end{array}$ & & $\begin{array}{c}0.002 \\
(0.001)\end{array}$ \\
\hline & & & & & & & & & & & & \\
\hline Q (24) & 0.124 & 0.704 & 0.358 & 0.740 & & & 0.596 & 0.476 & 0.854 & 0.370 & 0.843 & 0.443 \\
\hline Q (24) sq. & 0.108 & 1.000 & 0.872 & 1.000 & 0.856 & 0.514 & 0.925 & 0.019 & 0.859 & 0.026 & 0.956 & 0.018 \\
\hline
\end{tabular}

Note: Standard errors are reported in parentheses. The residual diagnostics are presented as p-values. Q (24) is the portmanteau statistic, which explains the null hypothesis of no residual serial correlations, gauged through a lag of 24 . Using the same method, Q (24) sq. indicates the null hypothesis of no residual ARCH effect. * and ** denote significance at 95 percent $(p<0.05)$ and 99 percent $(p<0.01)$, respectively.

Source: Authors' calculations.

\section{Figure 6: Pre-CPEC volatility of returns}

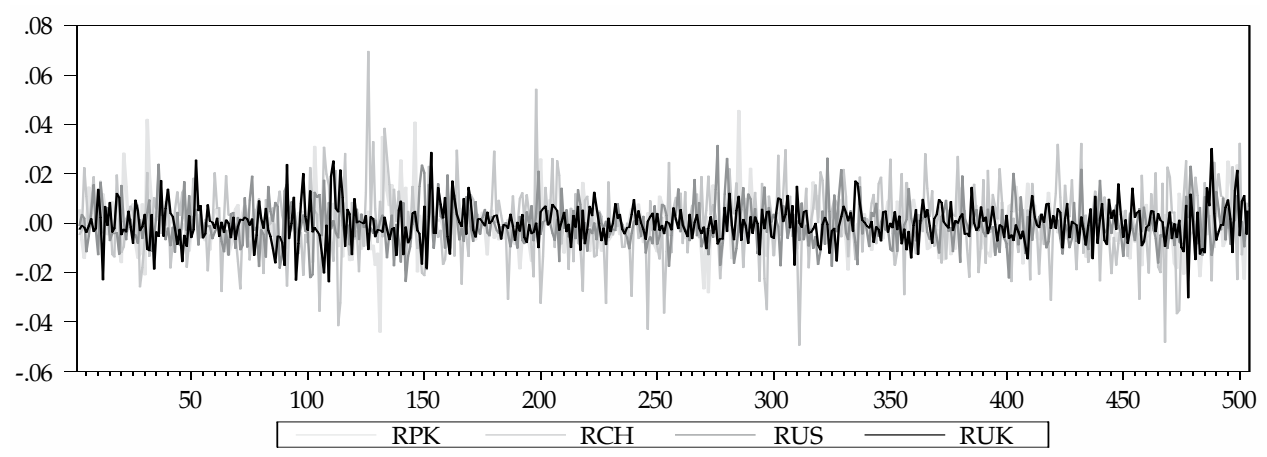




\section{Figure 7: Post-CPEC volatility of returns}

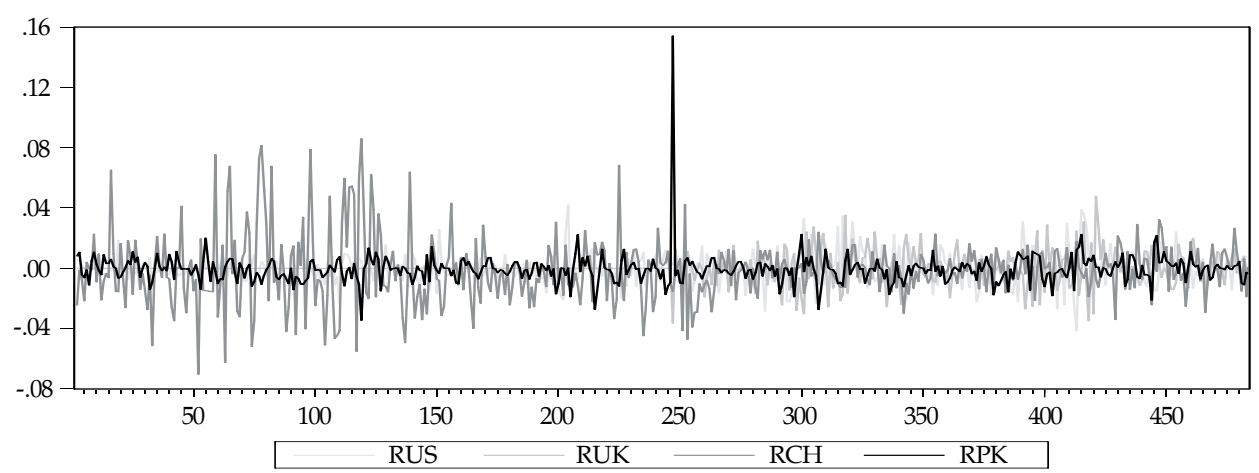

We use the ADF and PP tests to measure the co-movement among the indices. The results show that all the indices are nonstationary at level and stationary at first difference over the period 2013-17 (Table A5 in the Appendix). To measure the lag length, we use the log likelihood, AIC and SIC (Table A6 in the Appendix). Table 7 indicates the co-movement of the PSX with all the indices. The results suggest that the PSX follows these indices, although the mean, volatility and co-movement results for the postCPEC period point to a paradigm shift (Figure 8), that is, the PSX tends to converge on the SZSE post-CPEC.

Table 7: Co-movement of indices, 2013-17

\begin{tabular}{|c|c|c|c|c|c|c|c|c|c|}
\hline & PSX & Nasdaq & FTSE 100 & SZSE & & PSX & Nasdaq & FTSE 100 & SZSE \\
\hline \multirow[t]{3}{*}{$\operatorname{PSX}(-1)$} & 1.1191 & -0.0108 & 0.0069 & -0.0246 & FTSE100 (-1) & 0.5296 & 0.0848 & 0.9583 & 0.0406 \\
\hline & -0.0509 & -0.0114 & -0.0076 & -0.0067 & & -0.2821 & -0.0629 & -0.0422 & -0.0372 \\
\hline & [21.971] & {$[-0.952]$} & [0.902] & {$[-3.653]$} & & [1.877] & [1.347] & [22.702] & [1.089] \\
\hline \multirow[t]{3}{*}{ PSX (-2) } & -0.1214 & 0.0116 & -0.0065 & 0.0247 & FTSE100 (-2) & -0.5810 & -0.0811 & 0.0179 & -0.0622 \\
\hline & -0.0509 & -0.0114 & -0.0076 & -0.0067 & & -0.2835 & -0.0633 & -0.0424 & -0.0374 \\
\hline & {$[-2.382]$} & [1.020] & {$[-0.853]$} & [3.666] & & {$[-2.049]$} & {$[-1.281]$} & [0.422] & {$[-1.661]$} \\
\hline \multirow[t]{3}{*}{ Nasdaq (-1) } & -0.1219 & 0.9907 & -0.0141 & -0.0346 & $\operatorname{SZSE}(-1)$ & 0.0549 & 0.1341 & -0.0552 & 1.2984 \\
\hline & -0.1949 & -0.0435 & -0.0292 & -0.0258 & & -0.3848 & -0.0859 & -0.0575 & -0.0508 \\
\hline & {$[-0.625]$} & [22.771] & {$[-0.484]$} & [-1.343] & & [0.142] & [1.562] & [-0.959] & [25.541] \\
\hline \multirow[t]{3}{*}{ Nasdaq (-2) } & 0.0504 & -0.0017 & 0.0173 & 0.0356 & SZSE (-2) & -0.1101 & -0.1420 & 0.0492 & -0.3170 \\
\hline & -0.1971 & -0.0440 & -0.0295 & -0.0260 & & -0.3828 & -0.0854 & -0.0572 & -0.0505 \\
\hline & {$[0.255]$} & {$[-0.038]$} & [0.587] & [1.368] & & {$[-0.287]$} & {$[-1.661]$} & [0.859] & {$[-6.268]$} \\
\hline \multirow[t]{3}{*}{ C } & 853.0373 & 10.6367 & 134.1324 & 159.7401 & & & & & \\
\hline & -493.3200 & -110.1200 & -73.8021 & -65.1662 & & & & & \\
\hline & [1.729] & [0.096] & [1.817] & [2.451] & & & & & \\
\hline
\end{tabular}

Source: Authors' calculations. 
Figure 8: Co-movement of market returns, 2013-17

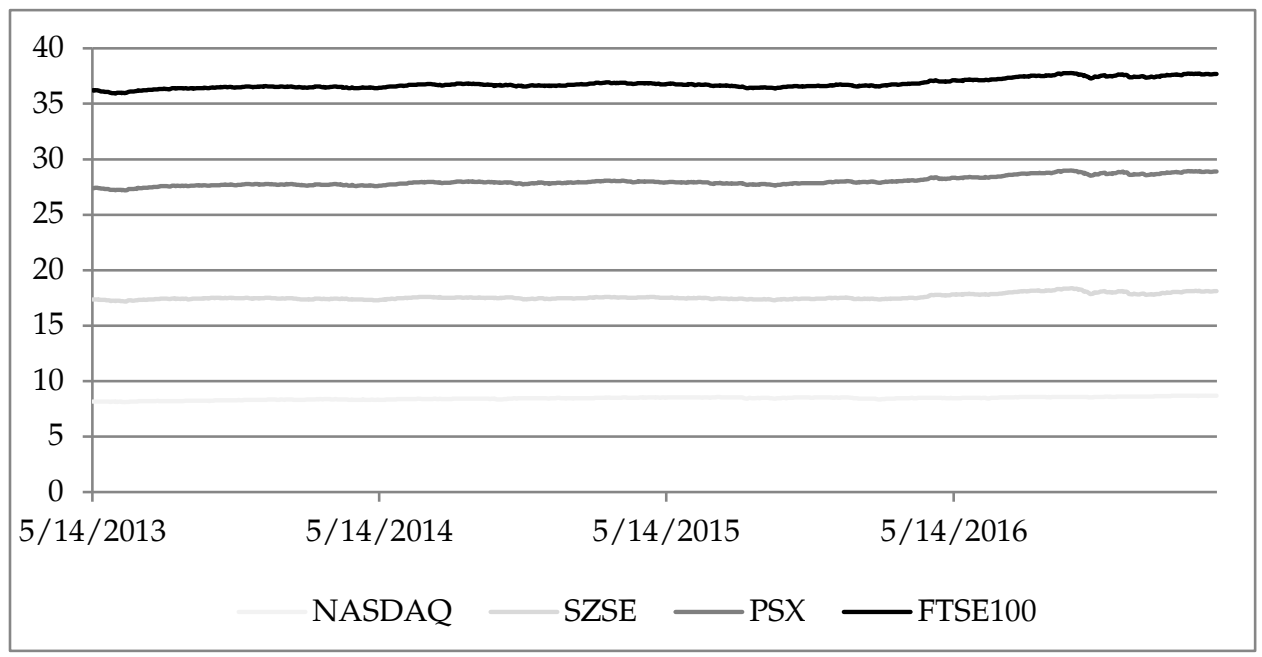

Table 8 gives the results of the Granger causality test, indicating that the PSX followed the SZSE, FTSE 100 and Nasdaq from 2006 to 2017.

Table 8: Granger causality test results

\begin{tabular}{lcccc}
\hline & \multicolumn{2}{c}{ Post-FTA } & \multicolumn{2}{c}{ Post-CPEC } \\
\cline { 2 - 5 } & F-stat & Prob. & F-stat & Prob. \\
\hline SZSE does not Granger-cause PSX & 3.7945 & 0.0099 & 0.4122 & 0.6623 \\
PSX does not Granger-cause SZSE & 8.2670 & $2.00 \mathrm{E}-05$ & 7.5076 & 0.0006 \\
Nasdaq does not Granger-cause PSX & 0.6782 & 0.5653 & 2.4582 & 0.0865 \\
PSX does not Granger-cause Nasdaq & 9.1497 & $5.00 \mathrm{E}-06$ & 0.5424 & 0.5816 \\
FTSE 100 does not Granger-cause PSX & 0.7664 & 0.5127 & 2.0398 & 0.1310 \\
PSX does not Granger-cause FTSE 100 & 2.9646 & 0.0309 & 0.1721 & 0.8419 \\
\hline
\end{tabular}

Source: Authors' calculations.

\subsection{Financial Crisis}

Financial crises will, naturally, affect stock market activities. This study considers the financial crisis of 2007/08, using OLS and a qualitative regressor. The dependent variable is the stock index and the independent variables are divided into three categories: pre-crisis period (BC1-BC5), crisis period (CRS1-CRS2) and post-crisis period (ACRS1-ACRS5). Table 9 shows that all the stock indices trended downward during the financial crisis period, which implies that the crisis affected their stability, soundness and responsiveness to economic shocks. The Nasdaq and PSX appear to have been affected less than the FTSE 100 and SZSE (Figure 9). The key factor is 
the soundness and stability of international institutional investors and integration with stable international markets.

Table 9: Crisis effects

\begin{tabular}{lcccc}
\hline & SZSE & FTSE 100 & PSX & Nasdaq \\
\hline bc1 & $9,186.718$ & $1,695.930$ & $46,954.019$ & $4,077.659$ \\
bc2 & $10,169.799$ & $2,594.241$ & $46,304.270$ & $4,492.606$ \\
bc3 & $10,098.984$ & $3,281.297$ & $44,789.807$ & $4,353.138$ \\
bc4 & $9,856.796$ & $2,774.718$ & $42,943.060$ & $4,019.510$ \\
bc5 & $10,384.464$ & $2,165.949$ & $40,421.865$ & $3,911.774$ \\
crs1 & -459.658 & $8,600.906$ & $35,396.070$ & $3,424.790$ \\
crs2 & $2,995.280$ & $1,740.914$ & $36,871.581$ & $3,863.429$ \\
acrs1 & $2,509.926$ & $2,754.980$ & $40,515.004$ & $4,155.847$ \\
acrs2 & $1,690.975$ & $1,888.968$ & $38,013.063$ & $3,678.469$ \\
acrs3 & $1,962.153$ & $1,511.497$ & $36,448.124$ & $3,311.800$ \\
acrs4 & $4,153.195$ & $1,577.922$ & $33,699.082$ & $3,028.149$ \\
acrs5 & $4,702.849$ & $1,695.922$ & $27,030.689$ & $2,437.235$ \\
\hline
\end{tabular}

Note: ${ }^{*} p<0.05,{ }^{* *} p<0.01$.

Source: Authors' calculations.

Figure 9: Market indices growth during financial crisis period

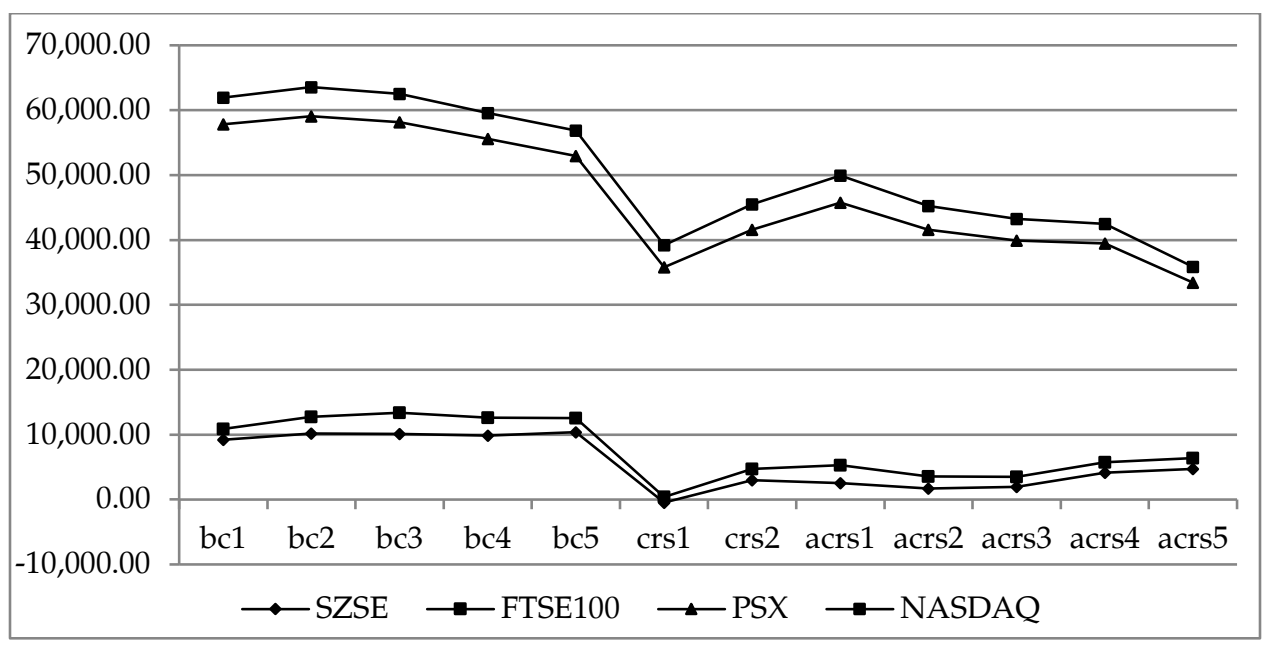

\subsection{Pre-Event and Post-Event Variance Analysis}

This section applies the F-test to examine the distribution of the variances of two populations, that is, to gauge if the pre-selection and postselection of events is equal. Table 10 reports the results of the F-test and shows that, pre-FTA and post-FTA for each index, there is strong evidence 
in favor of rejecting the null hypothesis. This implies that the pre-FTA and post-FTA variances are not equal at the 5 percent significance level. It also suggests that the increase in overall performance of the PSX is due to its connection with the Chinese stock market.

Table 10: F-test results

\begin{tabular}{|c|c|c|c|c|c|}
\hline Event & $\begin{array}{c}\text { Stock } \\
\text { exchange }\end{array}$ & Pre-event & Post-event & F-value & $\begin{array}{l}(2 * \operatorname{Pr}(F<f)) \\
\text { Ha: ratio }=1\end{array}$ \\
\hline \multirow[t]{4}{*}{ FTA 2006} & PSX & $\begin{array}{c}4,315.324 \\
(2,715.511)\end{array}$ & $\begin{array}{c}7,934.807 \\
(4,097.611)\end{array}$ & 0.4392 & 0.000 \\
\hline & Nasdaq & $\begin{array}{c}1,860.721 \\
(308.6315)\end{array}$ & $\begin{array}{c}2,107.501 \\
(397.1716)\end{array}$ & 0.6038 & 0.000 \\
\hline & FTSE 100 & $\begin{array}{l}4,761.234 \\
(616.894)\end{array}$ & $\begin{array}{c}5,200.969 \\
(773.4536)\end{array}$ & 0.6361 & 0.000 \\
\hline & SZSE & $\begin{array}{l}3,257.996 \\
(720.009)\end{array}$ & $\begin{array}{c}5,901.661 \\
(4,326.349)\end{array}$ & 0.0277 & 0.000 \\
\hline \multirow[t]{4}{*}{$\begin{array}{l}\text { Financial } \\
\text { crisis 2007/08 }\end{array}$} & PSX & $\begin{array}{l}6,182.441 \\
(3,238.34)\end{array}$ & $\begin{array}{c}18,917 \\
(7,937.664)\end{array}$ & 0.1664 & 0.000 \\
\hline & Nasdaq & $\begin{array}{l}1,906.947 \\
(322.241)\end{array}$ & $\begin{array}{l}3,181.476 \\
(740.524)\end{array}$ & 0.1894 & 0.000 \\
\hline & FTSE 100 & $\begin{array}{l}4,856.567 \\
(726.793)\end{array}$ & $\begin{array}{l}6,016.433 \\
(526.740)\end{array}$ & 1.9038 & 0.000 \\
\hline & SZSE & $\begin{array}{l}3,437.325 \\
(565.065)\end{array}$ & $\begin{array}{c}10,276 \\
(1,943.049)\end{array}$ & 0.0846 & 0.000 \\
\hline \multirow[t]{4}{*}{ СРЕС 2015} & PSX & $\begin{array}{c}38,986.58 \\
(5,568.159)\end{array}$ & $\begin{array}{l}8,963.208 \\
(702.869)\end{array}$ & 62.758 & 0.000 \\
\hline & Nasdaq & $\begin{array}{l}5,098.824 \\
(361.204)\end{array}$ & $\begin{array}{l}4,290.998 \\
(435.970)\end{array}$ & 0.6864 & 0.000 \\
\hline & FTSE 100 & $\begin{array}{c}6,415.03 \\
(248.526)\end{array}$ & $\begin{array}{l}6,684.891 \\
(180.995)\end{array}$ & 1.8854 & 0.000 \\
\hline & SZSE & $\begin{array}{c}10,241.64 \\
(2,819.828)\end{array}$ & $\begin{array}{l}8,963.208 \\
(702.869)\end{array}$ & 16.0952 & 0.000 \\
\hline
\end{tabular}

Source: Authors' calculations.

From Pakistan's perspective, the strength of the FTA lies in the considerable growth of overall exports to China since the year it was enforced. China's exports to Pakistan have also gained momentum, climbing by US $\$ 13$ billion between 2006 and 2014. This substantial increase in Chinese imports is associated with the lower price of Chinese products, trade diversions due to lower transportation costs and smaller tariffs imposed by Pakistan on Chinese products. Consequently, China is now Pakistan's top importing partner. 
Likewise, the pre-crisis and post-crisis statistics for each index enable us to reject the null hypothesis that the pre-event and post-event variances are not equal at the 0.05 significance level. We also find that the volatility of stock returns increased across all the markets under study. In general, the positive return spillover effects are unidirectional, running from both the US and UK to the PSX and SZSE. In the CPEC case, the post-event and pre-event variances are not equal at the 5 percent significance level, implying that Pakistan's financial and strategic integration with China has influenced the PSX, resulting in a multilateral economic order (Epaulard \& Pommeret, 2016). The dependency of the PSX on the SZSE has thus increased.

Cross-border transactions through depository certificates and crossborder listings introduce further challenges and complexities, making it necessary for institutions to be well equipped and aware of the relevant legal procedures of both countries. Integration implies that the economic shocks and high volatility experienced in one economy could put pressure on its strategic partners, as in the case of the impact of the SZSE on the PSX. These factors need to be incorporated into estimations and forecasts to enable more effective risk management.

\section{Theoretical Contribution and Practical Implications}

This paper makes an important contribution to the theoretical literature as well as highlighting practical implications for policymakers and managers. The key insight is that, after demutualization and the CPEC agreement, trading activities were enhances when Chinese companies floated shares on the PSX through cross-listing, cross-border transactions and depository certificates. This has increased competition in the local market and created regulatory challenges, but it has also generated demand for better control management and risk management at the micro and macro levels of market operations.

Since cross-border transactions introduce additional complexities, regulatory bodies such as the PSX and Securities and Exchange Commission of Pakistan need to be aware of the legal and regulatory procedures that govern cross-listing and cross-border transactions. Financial integration includes a degree of risk, but also potentially allows risk sharing (Epaulard \& Pommeret, 2016). Economic shocks to China's economy could penetrate Pakistan's capital market. This needs to be incorporated into decision making and forecasts to ensure financial stability and market performance in the future. 
In addition, the study provides insights relevant to investment decisions in terms of company cross-listing and depository certificates for individual investors. We suggest that the paradigm shift will enable firms to avail a more diversified pool of resources, but that they should maintain similar levels of local and international shareholdings to accommodate international market fluctuations. Managers should be aware that market competition will increase as financial integration with China progresses. However, an additional benefit for the PSX will be the transfer of expertise and market knowledge from Chinese companies cross-listed on the Nasdaq and FTSE 100, including best practices from a regulatory perspective, technical capacity building, improved financial forecasting and investors' protection. On the other hand, managers will need to be equipped to deal with the complexities associated with cross-border transactions and business.

The findings of this study may be of interest to regulatory bodies and policymakers, who should keep in mind that local companies will now face greater competition. The rising cost of local businesses (cost-push inflation) due to the energy crisis and high levels of taxation could affect profitability and marketability vis-à-vis the more well-established Chinese firms, thereby posing a threat to local business survival. Policymakers and regulatory bodies should focus on improving the country's stock market volume and strengthening enforcement strategies, so that cross-listed firms and local firms are valued fairly. Similarly, policymakers should be aware that smaller local investors may not be equipped to deal with international market trends and strategies. Their capacity could be enhanced through outreach and training in international business strategies.

\section{Conclusion}

This study examines return and volatility spillovers and comovements between the PSX and a sample of international and regional indices. We look specifically at pre-event and post-event subsamples to account for the impact of the FTA and CPEC. We find that, during 2006-15 (post-FTA), the PSX was influenced by return and volatility spillovers from global stock indices. Integration with the global market in this case implies that any systematic and unsystematic risks in the latter will affect the returns and variances of regional and local markets. Since Pakistan's economy was integrated with the US and UK markets during 2001-17, any substantial changes would have had a significant impact on the PSX.

Alternatively, when we look at the post-CPEC impact of the SZSE as a regional market, the demutualization of the PSX and strategic partnership 
with the Chinese consortium, the results for mean and volatility spillovers and co-movement indicate a paradigm shift that should be closely monitored in the coming years. Pakistan's financial and strategic integration with China has clearly influenced the PSX, resulting in a multilateral economic order (Epaulard \& Pommeret, 2016). The PSX is now more dependent on the SZSE. Both scenarios support convergence theory. In the post-FTA scenario, the degree of financial integration was not strong enough to affect the PSX directly, as the stock market was not directly associated with the commodities market. In the post-CPEC scenario, when the Chinese consortium acquired 40 percent of PSX shares, this had a direct impact on the stock exchange's movements and behavior.

This study contributes to an important area of research - whether regional connectivity causes the dependency of regional markets on each other. We explore significant outperformance, including index stability and soundness, to see if this proposition is justified. Our findings support the argument, indicating that the overall market efficiency and performance of regional stock exchanges is higher than before. Further research could analyze whether these stock exchanges can enhance their market performance and growth by integrating their activities with local and regional forums, and diversifying the strategic partners involved in their governance structure. 


\section{References}

Alikhanov, A. (2013). To what extent are stock returns driven by mean and volatility spillover effects? Evidence from eight European stock markets. Review of Economic Perspectives, 13(1), 3-29.

Barro, R. J. (2016). Economic growth and convergence, applied to China. China and World Economy, 24(5), 5-19.

Bhar, R., \& Nikolova, B. (2007). Analysis of mean and volatility spillovers using BRIC countries, regional and world equity index returns. Journal of Economic Integration, 22(2), 369-381.

Carsamer, E. (2016). Volatility transmission in African foreign exchange markets. African Journal of Economic and Management Studies, 7(2), 205-224.

Choudhry, T. (2004). International transmission of stock returns and volatility: Empirical comparison between friends and foes. Emerging Markets Finance and Trade, 40(4), 33-52.

Dedi, L., \& Yavas, B. F. (2016). Return and volatility spillovers in equity markets: An investigation using various GARCH methodologies. Cogent Economics and Finance, 4(1). doi.org/10.1080/23322039.2016. 1266788

Ely, R. A. (2015). Volatility spillovers and the risk-return relation between stock and foreign exchange markets in Brazil. Latin American Business Review, 16(4), 305-325.

Epaulard, A., \& Pommeret, A. (2016). Financial integration, growth and volatility. Pacific Economic Review, 21(3), 330-357.

Fedderke, J. W., \& Marinkov, M. (2016). Diagnosing the source of financial market shocks: An application to the Asian, subprime and European financial crises. Pacific Economic Review. doi.org/10.1111/1468-0106.12162

Granger, C. W. J. (1986). Developments in the study of cointegrated economic variables. Oxford Bulletin of Economics and Statistics, 48(3), 213-228. 
Gunasinghe, W. (2005). Behavior of stock markets in South Asia: An econometric investigation. South Asia Economic Journal, 6(2), 166-191.

Hatipoglu, O., \& Uyar, O. (2012). Do bubbles spill over? Estimating financial bubbles in emerging markets. Emerging Markets Finance and Trade, 48(5), 64-75.

Hussain, D. (2016, December 23). PSX sells 40pc stake to Chinese consortium. Dawn. Retrieved from https://www.dawn.com/news/1304006

Hussain, S. M., Korkeamäki, T., Xu, D., \& Khan, A. H. (2015). What drives stock market growth? A case of a volatile emerging economy. Emerging Markets Finance and Trade, 51(1), 209-223.

Jebran, K., \& Iqbal, A. (2016). Dynamics of volatility spillover between stock market and foreign exchange market: Evidence from Asian countries. Financial Innovation, 2(3), 1-20.

Joshi, P. (2011). Return and volatility spillovers among Asian stock markets. SAGE Open. doi.org/10.1177/2158244011413474

Li, H., \& Majerowska, E. (2008). Testing stock market linkages for Poland and Hungary: A multivariate GARCH approach. Research in International Business and Finance, 22(3), 247-266.

Liow, K. H. (2015). Volatility spillover dynamics and relationship across G7 financial markets. North American Journal of Economics and Finance, 33, 328-365.

Masih, R., \& Masih, A. (2001). Long and short term dynamic causal transmission amongst international stock markets. Journal of International Money and Finance, 20(4), 563-587.

Morana, C., \& Beltratti, A. (2008). Co-movements in international stock markets. Journal of International Financial Markets, Institutions and Money, 18(1), 31-45.

Mulyadi, M. S., \& Anwar, Y. (2012). Return and volatility spillover across USA and Europe (study of American and EU crisis period). African Journal of Business Management, 6(19), 5916-5926. 
Patel, R. (2016). An empirical study of co-movement in selected stock exchanges. Asia-Pacific Journal of Management Research and Innovation, 12(1), 23-30.

Patel, R., \& Patel, M. (2012). A study of co-movement and interdependence of Indian stock market with selected stock markets. SS International Journal of Business and Management Research, 2(5), 1-8.

Peng, C.-L, Chung, C.-F., Tsai, C.-C., \& Wang, C.-T. (2017). Exploring the returns and volatility spillover effect in Taiwan and Japan stock markets. Asian Economic and Financial Review, 7(2), 175-187.

Rajhans, R. K., \& Jain, A. (2015). Volatility spillover in foreign exchange markets. Paradigm, 19(2), 137-151.

Sehgal, S., Ahmad, W., \& Deisting, F. (2015). An investigation of price discovery and volatility spillovers in India's foreign exchange market. Journal of Economic Studies, 42(2), 261-284.

Sial, A. W., Talib, N., Ashkanani, F. A., \& Alam, M. A. (2015). Demutualization of stock exchanges: A corporate blessing in disguise for stock market growth. Strategic Change, 24(4), 389-400.

Singhania, M., \& Anchalia, J. (2013). Volatility in Asian stock markets and global financial crisis. Journal of Advances in Management Research, 10(3), 333-351.

Taly, I. (2015). Study on return and volatility spillover effects among stock, CDS, and foreign exchange markets in Korea. East Asian Economic Review, 19(3), 275-322.

Taneja, Y. P. (2012). Stock market integration: A study of world's major stock exchanges with special reference to India. Vision: The Journal of Business Perspective, 16(2), 109-120.

Tanizaki, H., \& Hamori, S. (2009). Volatility transmission between Japan, UK and USA in daily stock returns. Empirical Economics, 36(1), 27-54.

Valadkhani, A., \& Chen, G. (2014). An empirical analysis of the US stock market and output growth volatility spillover effects on three Anglo-Saxon countries. International Review of Applied Economics, 28(3), 323-335. 
Wang, Y., \& Liu, L. (2016). Spillover effect in Asian financial markets: A VAR-structural GARCH analysis. China Finance Review International, 6(2), 150-176.

Zhang, C., Song, K., \& Wang, F. (2015). Economic globalization and inflation in China: A multivariate approach. China and World Economy, 23(3), 79-96. 


\section{Appendix}

Table A1: Unit root test results for overall sample

\begin{tabular}{lcccccccc}
\hline & \multicolumn{4}{c}{ ADF test } & \multicolumn{4}{c}{ PP test } \\
\cline { 2 - 9 } & \multicolumn{2}{c}{ Level } & \multicolumn{2}{c}{ First difference } & \multicolumn{2}{c}{ Level } & \multicolumn{2}{c}{ First difference } \\
\cline { 2 - 10 } & $\begin{array}{c}\text { With } \\
\text { intercept }\end{array}$ & $\begin{array}{c}\text { With } \\
\text { intercept } \\
\text { and trend }\end{array}$ & $\begin{array}{c}\text { With } \\
\text { intercept }\end{array}$ & $\begin{array}{c}\text { With } \\
\text { intercept } \\
\text { and trend }\end{array}$ & $\begin{array}{c}\text { With } \\
\text { intercept }\end{array}$ & $\begin{array}{c}\text { With } \\
\text { intercept } \\
\text { and trend }\end{array}$ & $\begin{array}{c}\text { With } \\
\text { intercept }\end{array}$ & $\begin{array}{c}\text { With } \\
\text { intercept } \\
\text { and trend }\end{array}$ \\
\hline PSX & 1.926 & -0.305 & -56.765 & -56.840 & 2.089 & -0.188 & -56.606 & -56.627 \\
Prob. & 1.000 & 0.990 & 0.000 & 0.000 & 1.000 & 1.000 & 0.000 & 0.000 \\
Nasdaq & 0.271 & -2.440 & -64.559 & -64.604 & 0.407 & -2.337 & -64.639 & -64.715 \\
Prob. & 0.980 & 0.360 & 0.000 & 0.000 & 0.980 & 0.410 & 0.000 & 0.000 \\
SZSE & -2.526 & -3.943 & -19.668 & -19.666 & -2.289 & -3.601 & -57.643 & -57.636 \\
Prob. & 0.110 & 0.010 & 0.000 & 0.000 & 0.180 & 0.030 & 0.000 & 0.000 \\
FTSE 100 & -2.134 & -3.447 & -67.141 & -67.141 & -1.871 & -3.190 & -67.688 & -67.696 \\
Prob. & 0.230 & 0.050 & 0.000 & 0.000 & 0.350 & 0.090 & 0.000 & 0.000 \\
\hline
\end{tabular}

Note: Critical ADF test values: $-3.438,-2.864$ and -2.568 , significant at 1,5 and 10 percent, with only intercept. Critical PP test values: $-3.970,-3.415$ and -3.129 , significant at 1,5 and 10 percent, with intercept and trend.

Source: Authors' calculations.

Table A2: Lag length results for overall sample

\begin{tabular}{lccccc}
\hline Test & Lag & PSX & Nasdaq & FTSE 100 & SZSE \\
\hline Log likelihood & 2 & $-27,502.58$ & $-21,274.59$ & $-22,714.22$ & $-18,730.38$ \\
AIC & & 13.3908 & 10.3595 & 11.0602 & 9.1211 \\
SIC & & 13.4047 & 10.3733 & 11.0740 & 9.1349 \\
Log likelihood & 3 & $-27,489.76$ & $-21,262.9$ & $-22,705.68$ & $-18,718.84$ \\
AIC & & 13.3898 & 10.3582 & 11.0607 & 9.1196 \\
SIC & & 13.4098 & 10.3782 & 11.0807 & 9.1396 \\
Log likelihood & 4 & $-27,476.65$ & $-21,255.75$ & $-22,698.36$ & $-18,701.30$ \\
AIC & & 13.3886 & 10.3592 & 11.0617 & 9.1153 \\
SIC & & 13.4148 & 10.3854 & 11.0879 & 9.1414 \\
\hline Hypothesized no. & Eigenvalue & Trace statistic & Critical value & Prob.** & \\
of CE(s) & & & & & \\
\hline None & 0.0092 & 74.6313 & 47.8561 & 0.00 & \\
At most 1 & 0.0060 & 36.3170 & 29.7971 & 0.00 & \\
At most 2 & 0.0023 & 11.7390 & 15.4947 & 0.17 & \\
At most 3 & 0.0005 & 2.07978 & 3.84147 & 0.15 & \\
\hline
\end{tabular}

Note: At lag 3, all the test values are at a minimum level, indicating the appropriate lag order and vector decomposition. The results of the trace test indicate two co-integrating equations at the 5 percent level.

Source: Authors' calculations. 
Table A3: Unit root test results for pre-FTA and post-FTA data

\begin{tabular}{lcccccccc}
\hline & \multicolumn{4}{c}{ ADF test } & \multicolumn{4}{c}{ PP test } \\
\cline { 2 - 9 } & \multicolumn{2}{c}{ Level } & \multicolumn{2}{c}{ First difference } & \multicolumn{2}{c}{ Level } & \multicolumn{2}{c}{ First difference } \\
\cline { 2 - 9 } & $\begin{array}{c}\text { With } \\
\text { intercept }\end{array}$ & $\begin{array}{c}\text { With } \\
\text { intercept } \\
\text { and } \\
\text { trend }\end{array}$ & $\begin{array}{c}\text { With } \\
\text { intercept }\end{array}$ & $\begin{array}{c}\text { With } \\
\text { intercept } \\
\text { and } \\
\text { trend }\end{array}$ & $\begin{array}{c}\text { With } \\
\text { intercept }\end{array}$ & $\begin{array}{c}\text { With } \\
\text { intercept } \\
\text { and } \\
\text { trend }\end{array}$ & $\begin{array}{c}\text { With } \\
\text { intercept }\end{array}$ & $\begin{array}{c}\text { With } \\
\text { intercept } \\
\text { and } \\
\text { trend }\end{array}$ \\
\hline PSX & 1.926 & -0.305 & -56.765 & -56.840 & 2.089 & -0.188 & -56.606 & -56.627 \\
Prob. & 0.9999 & 0.991 & 0.000 & 0.000 & 0.9999 & 0.993 & 0.000 & 0.000 \\
Nasdaq & 0.271 & -2.440 & -64.559 & -64.604 & 0.407 & -2.337 & -64.639 & -64.715 \\
Prob. & 0.977 & 0.359 & 0.000 & 0.000 & 0.983 & 0.413 & 0.000 & 0.000 \\
SZSE & -2.526 & -3.943 & -19.668 & -19.666 & -2.289 & -3.601 & -57.643 & -57.636 \\
Prob. & 0.109 & 0.011 & 0.000 & 0.000 & 0.176 & 0.030 & 0.000 & 0.000 \\
FTSE100 & -2.134 & -3.447 & -67.141 & -67.141 & -1.871 & -3.190 & -67.688 & -67.696 \\
Prob. & 0.231 & 0.046 & 0.000 & 0.000 & 0.346 & 0.087 & 0.000 & 0.000 \\
\hline
\end{tabular}

Note: Critical ADF test values: $-3.438,-2.864$ and -2.568 , significant at 1,5 and 10 percent, with only intercept. Critical PP test values: $-3.970,-3.415$ and -3.129 , significant at 1,5 and 10 percent, with intercept and trend.

Source: Authors' calculations.

Table A4: Lag length results for pre-FTA and post-FTA data

\begin{tabular}{lccccc}
\hline Test & Lag & PSX & Nasdaq & FTSE 100 & SZSE \\
\hline Log likelihood & 2 & $-27,502.580$ & $-21,274.590$ & $-22,714.220$ & $-18,730.380$ \\
AIC & & 13.391 & 10.360 & 11.060 & 9.121 \\
SIC & & 13.405 & 10.373 & 11.074 & 9.135 \\
Log likelihood & 3 & $-27,489.760$ & $-21,262.900$ & $-22,705.680$ & $-18,718.840$ \\
AIC & & 13.390 & 10.358 & 11.061 & 9.120 \\
SIC & & 13.410 & 10.378 & 11.081 & 9.140 \\
Log likelihood & 4 & $-27,476.650$ & $-21,255.750$ & $-22,698.360$ & $-18,701.300$ \\
AIC & & 13.389 & 10.359 & 11.062 & 9.115 \\
SIC & & 13.415 & 10.385 & 11.088 & 9.141 \\
\hline Hypothesized no. & Eigenvalue & Trace statistic & Critical value & Prob.** & \\
of CE(s) & & & & & \\
\hline None* & 0.009 & 74.631 & 47.856 & 0.000 & \\
At most 1* & 0.006 & 36.317 & 29.797 & 0.008 & \\
At most 2 & 0.002 & 11.739 & 15.495 & 0.170 & \\
At most 3 & 0.001 & 2.080 & 3.841 & 0.149 & \\
\hline
\end{tabular}

Note: At lag 3, all the test values are at a minimum level, indicating the appropriate lag order and vector decomposition. The results of the trace test indicate two co-integrating equations at the 5 percent level.

Source: Authors' calculations. 
Table A5: Unit root test results for pre-CPEC and post-CPEC data

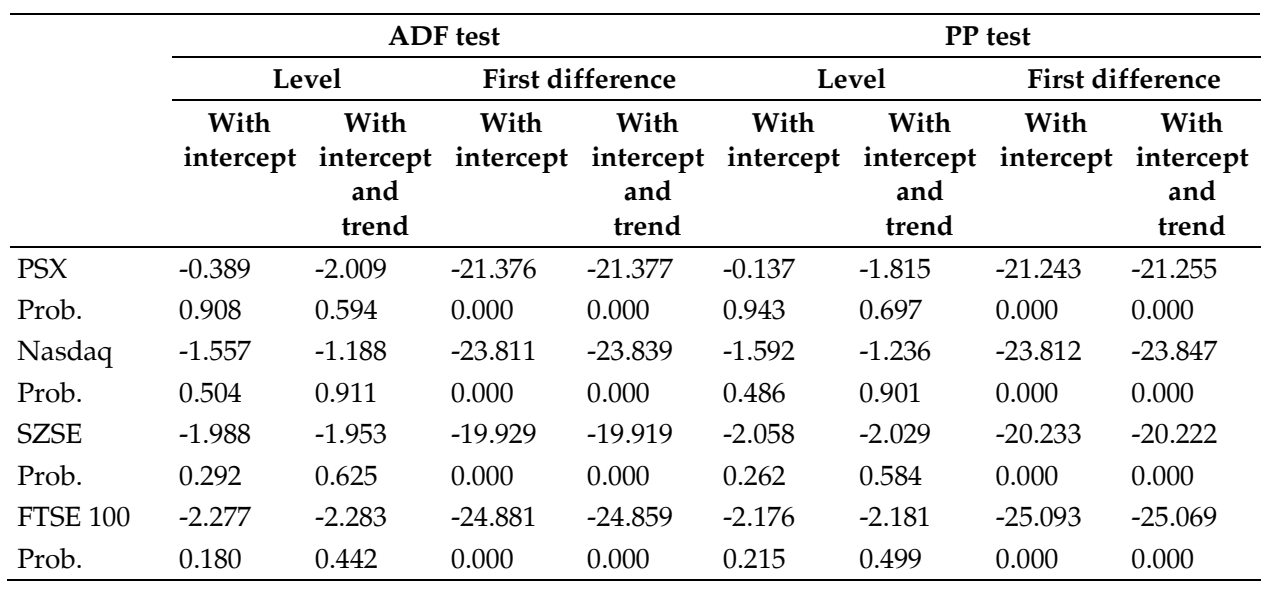

Note: Critical ADF test values: $-3.438,-2.864$ and -2.568 , significant at 1,5 and 10 percent, with only intercept. Critical PP test values: $-3.970,-3.415$ and -3.129 , significant at 1,5 and 10 percent, with intercept and trend.

Source: Authors' calculations.

\section{Table A6: Lag length results for pre-CPEC and post-CPEC data}

\begin{tabular}{lccccc}
\hline Test & Lag & PSX & Nasdaq & FTSE 100 & SZSE \\
\hline Log likelihood & 2 & $-4,243.794$ & $-3,374.032$ & $-3,141.927$ & $-3,069.748$ \\
AIC & & 14.6648 & 11.6656 & 10.8652 & 10.6163 \\
SIC & & 14.7325 & 11.7333 & 10.9329 & 10.6840 \\
Log likelihood & 3 & $-4,231.098$ & $-3,363.696$ & $-3,135.605$ & $-3,060.667$ \\
AIC & & 14.6601 & 11.6638 & 10.8760 & 10.6171 \\
SIC & & 14.7580 & 11.7618 & 10.9739 & 10.7150 \\
Log likelihood & 4 & $-4,220.123$ & $-3,357.579$ & $-3,125.88$ & $-3,051.505$ \\
AIC & & 14.6613 & 11.6767 & 10.8750 & 10.6176 \\
SIC & & 14.7895 & 11.8049 & 11.0032 & 10.7458 \\
\hline Hypothesized no. & Eigenvalue & Trace statistic & Critical value & Prob.** & \\
of CE(s) & & & & & \\
\hline None & 0.0224 & 28.4997 & 47.8561 & 0.79 & \\
At most 1 & 0.0158 & 15.3325 & 29.7970 & 0.75 & \\
At most 2 & 0.0061 & 6.0612 & 15.4947 & 0.68 & \\
At most 3 & 0.0042 & 2.4806 & 3.8414 & 0.11 & \\
\hline
\end{tabular}

Note: At lag 2, all the test values are at a minimum level, indicating the appropriate lag order and vector decomposition. The results of the trace test indicate two co-integrating equations at the 5 percent level.

Source: Authors' calculations. 